\title{
Porcellanid crabs from Guadeloupe Island (Crustacea, Decapoda, Anomura), with an updated list of species from the Lesser Antilles
}

\author{
Joseph POUPIN \\ Institut de Recherche de l'École Navale, IRENav, BCRM de Brest, \\ Écoles Navale et groupe des écoles du Poulmic, CC 600, Lanvéoc, \\ F-29240 Brest cedex 09 (France) \\ joseph.poupin@ecole-navale.fr
}

Rafael LEMAITRE

Department of Invertebrate Zoology, National Museum of Natural History, Smithsonian Institution, 4210 Silver Hill Road, Suitland,

Maryland 20746 (USA)

lemaitrr@si.edu

KEY WORDS

Crustacea, Decapoda,

Porcellanidae,

Guadeloupe, Lesser Antilles,

Caribbean Sea, Inventory.
Poupin J. \& Lemaitre R. 2014. - Porcellanid crabs from Guadeloupe Island (Crustacea, Decapoda, Anomura), with an updated list of species from the Lesser Antilles. Zoosystema 36 (1): 5-27. http://dx.doi.org/10.5252/z2014n1a1

\section{ABSTRACT}

A collection of porcellanid crabs from Guadeloupe Island, Caribbean Sea Lesser Antilles, is reported. The specimens were obtained during the KARUBENTHOS Expedition (V.2012), a 1-month intensive survey of selected habitats in shallowwater to moderate depth (intertidal to $160 \mathrm{~m}$ ). A total of 20 species were found, 15 of which represent new records for Guadeloupe Island. Almost all species were photographed in color shortly after capture. For each species, a diagnosis, notes on habitat, geographical distribution, and taxonomic remarks, are given. The 20 species of porcellanid crabs found in Guadeloupe Island represent $54 \%$ of a total of 37 species known from the entire Lesser Antilles (Anguilla to Trinidad) and the islands off Venezuela (Testigos to Aruba). The richness of the porcellanid fauna of Guadeloupe Island indicates a high biodiversity potential in other decapod crustaceans or invertebrates in general, living in marine habitats of this Island. 
MOTS CLÉS

Crustacea, Decapoda,

Porcellanidae,

Guadeloupe,

Petites Antilles,

Mer des Caraïbes,

Inventaire.

\section{RÉSUMÉ}

Les crabes Porcellanidae de l'île de la Guadeloupe (Crustacea, Decapoda, Anomura), avec une liste actualisée des espèces des Petites Antilles.

Une collection de crabes Porcellanidae de la Guadeloupe, Petites Antilles, est étudiée. Les spécimens ont été récoltés pendant un mois de prospection intensive dans une sélection de biotopes situés de la zone intertidale jusqu'à des profondeurs modérées $(160 \mathrm{~m})$, au cours de la mission KARUBENTHOS (V.2012). Au total 20 espèces ont été trouvées, dont 15 nouveaux signalements pour la Guadeloupe. La plupart des espèces ont été photographiées en couleur, juste après leur capture. Une diagnose, des notes d'écologie, la distribution géographique et des remarques taxonomiques sont données pour chaque espèce. Les 20 crabes Porcellanidae de la Guadeloupe représentent $54 \%$ des 37 espèces connues pour l'ensemble des Petites Antilles (Anguilla à Trinidad) ainsi que les îles situées au large du Venezuela (Testigos à Aruba). La richesse de la faune des Porcellanidae à la Guadeloupe donne une indication de la grande biodiversité potentielle des habitats marins de cette île pour les autres décapodes et pour les invertébrés en général.

\section{INTRODUCTION}

The porcellanid crabs of Guadeloupe Island have been scantily studied, with only five species reported before this study. The oldest records seem to be those of Monod (1939) based on specimens collected during the "Mission P. Allorge, 1936" by M. Robert Lami, which included Neopisosoma angustifrons (Benedict, 1901), Pachycheles pilosus (H. Milne Edwards, 1837), and Petrolisthes politus (Gray, 1831). Two specimens collected by W. L. Schmitt from the "Îlet Rat", Guadeloupe, during the first 1956 Smithsonian-Bredin Caribbean expedition (Schmitt 1957), were deposited in the USNM, and later selected as the type specimens for Petrolisthes gertrudae Werding, 1996. One station was sampled around Guadeloupe Island in 11.VII.1969 by the University of Miami's Research Vessel "John Elliot Pillsbury" during a 3-year sampling period (19681971) throughout the Caribbean Sea. As a result, Gore (1974) reported Petrolisthes galathinus (Bosc, 1802) from the intertidal region in the southwest of Pointe-à-Pitre. In contrast to reports of only these five species from Guadeloupe Island, geographical distributions of porcellanid crabs by Werding et al. (2003: 81, tab. 1) and Rodríguez et al. (2005) count
36 species for the Lesser Antilles. Therefore, before this study began, it was obvious that porcellanid crab biodiversity in Guadeloupe Island was largely underestimated.

The KARUBENTHOS Expedition conducted in Guadeloupe Island during 2-30.V.2012, was organized jointly by the Parc National de Guadeloupe, the MNHN, the UAG, and the UPMC. It was an intensive sampling effort and opportunity to fill the lack of knowledge of marine organisms from this Island. This one-month expedition gathered 35 participants to inventory mollusks, decapod crustaceans, echinoderms and algae. All specimens collected were transported to Paris for deposition in MNHN, and subsequently an international workshop was organized by Dr. Philippe Bouchet (MNHN) in III.2013 at the Station Biologique, Université Blaise Pascal, Besse et St Anastaise, France, to sort and identify the numerous specimens. About 75 lots of porcellanids collected in various habitats ranging in depths from the intertidal to $160 \mathrm{~m}$, were processed during the workshop. All porcellanid species identified are herein reported and discussed. For each species, a diagnosis, habitat, distribution, and taxonomic remarks focused on the Lesser Antilles, are given. Color photographs 
of live or fresh specimens are presented for all the species. An annotated list of porcellanid species known to occur in the Lesser Antilles (including the Virgin Islands) is also provided.

\section{MATERIAL AND METHODS}

The specimens were collected using SCUBA-operated brush baskets (st. GB), dredging (st. GD), or by hand and snorkeling in intertidal to shallow water (st. GM), and SCUBA diving (st. GR). Baited traps (st. GN) and a SCUBA-operated vacuum device (st. GS) were also used, although no porcellanids were collected with those techniques. In total, about 270 stations were sampled during the KARUBENTHOS Expedition, with porcellanid crabs obtained in only 37 of these stations. The exact location of these stations are included in Table 1 and Figure 1A.

Habitats sampled included mangroves, intertidal or shallow waters (coral or coral rubble, sand, mud), seagrass beds, marine caves, and deeper coral and sponge bottoms. SCUBA dives were made within a depth range of 5-50 m; traps and dredges were operated mostly in depths of $10-100 \mathrm{~m}$, with a few in $100-160 \mathrm{~m}$.

The morphological terminology follows Osawa \& Chan (2010) and Gore \& Abele (1976). Measurements of specimens were taken to the nearest $0.1 \mathrm{~mm}$ and are listed as carapace length (measured from tip of rostrum to median posterior margin of carapace) by maximum carapace width (e.g., $2.9 \times 2.8 \mathrm{~mm}$ ).

References indicated for each species are limited to records for the Lesser Antilles. A comprehensive literature for the Caribbean porcellanids fauna can be found in Werding et al. (2003), Rodríguez et al. (2005) and Felder et al. (2009). The definition of the Lesser Antilles adopted in this study follows that of Chace \& Hobbs (1969) in their study on the freshwater and terrestrial decapod crustaceans of the West Indies, except that herein the Virgin Islands are also included. The Virgin Islands, separated from the Lesser Antilles by the deep-sea Anegada trench, should be considered as part of the Greater Antilles, together with Cuba, Jamaica, Haiti-Dominican Republic, and Puerto Rico, situated on the same geologic plate. However, as the Virgin Islands are often considered as the northern part of the Lesser Antilles, the literature records for these Islands are also included. To the south of the Lesser Antilles, Trinidad is herein included although, as pointed out by Chace \& Hobbs (1969: 16), it "should perhaps faunistically be considered more properly a part of South America". Within the Lesser Antilles a distributional distinction is made between the ICA (from Anguilla, Saba, in the north, to Tobago, Trinidad, in the south), and the IOV (from Los Testigos, Margarita, Coche, in the east, to Bonaire, Curaçao, Aruba, in the west; see Fig. 1B). The fauna of these latter islands are usually considered to be part of the fauna from the Venezuelan coast (e.g., Rodríguez 1980; Lira et al. 2001, 2007).

\section{ABBREVIATIONS}

\section{MORPHOLOGY \\ juv. juvenile; \\ ov ovigerous}

\section{GEOGRAPHY}

ICA Islands of the Caribbean arc;

IOV Islands off the Venezuelan coast.

\section{INSTITUTIONS}

MNHN Muséum national d'Histoire naturelle, Paris; UAG Université des Antilles et de la Guyane, Pointe-à-Pitre;

UPMC Université Pierre et Marie Curie, Paris;

USNM National Museum of Natural History, Smithsonian Institution, Washington, D.C.

\section{SYSTEMATICS}

Family PorCELlanidae Haworth, 1825

Megalobrachium mortenseni Haig, 1962

(Fig. 2A)

Megalobrachium mortenseni Haig, 1962: 189, figs 2-5 (Virgin Islands). - Lira 1997: 105, fig. 30 (Margarita). - Lira et al. 2001: 62 (Margarita). - Werding et al. 2003: 81, tab. 1 (Lesser Antilles). 
TABLE 1. - List of the 37 stations where porcellanid crabs were collected during 2012 KARUBENTHOS. The stations are ordered by station number. Distribution of these stations around Guadeloupe Islands is presented in Fig. $1 \mathrm{~A}$.

\begin{tabular}{|c|c|c|c|c|}
\hline Station & Latitude & Longitude & Date & Depth (m) \\
\hline GB01 & $16^{\circ} 11.8^{\prime} \mathrm{N}$ & $61^{\circ} 29.66^{\prime} \mathrm{W}$ & 3.V.2012 & 6 \\
\hline GB02 & $16^{\circ} 21.97^{\prime} \mathrm{N}$ & $61^{\circ} 37.98^{\prime} \mathrm{W}$ & 4.V.2012 & 11 \\
\hline GB06 & $16^{\circ} 22.9^{\prime} \mathrm{N}$ & $61^{\circ} 45.94^{\prime} \mathrm{W}$ & 8.V.2012 & 23 \\
\hline GB09 & $16^{\circ} 08.07^{\prime} \mathrm{N}$ & $61^{\circ} 46.71^{\prime} \mathrm{W}$ & 10.V.2012 & 6 \\
\hline GB15 & $16^{\circ} 22.57^{\prime} \mathrm{N}$ & $61^{\circ} 31.74^{\prime} \mathrm{W}$ & 15.V.2012 & 8 \\
\hline GB17 & $16^{\circ} 23.26^{\prime} \mathrm{N}$ & $61^{\circ} 31.79^{\prime} \mathrm{W}$ & 16.V.2012 & 13 \\
\hline GB18 & $16^{\circ} 25.99^{\prime} \mathrm{N}$ & $61^{\circ} 32.92^{\prime} \mathrm{W}$ & 17.V.2012 & 45 \\
\hline GB19 & $16^{\circ} 23.26^{\prime} \mathrm{N}$ & $61^{\circ} 31.79^{\prime} \mathrm{W}$ & 17.V.2012 & 11 \\
\hline GB20 & $16^{\circ} 26.78^{\prime} \mathrm{N}$ & $61^{\circ} 32.41^{\prime} \mathrm{W}$ & 18.V.2012 & 16 \\
\hline GB21 & $16^{\circ} 22.88^{\prime} \mathrm{N}$ & $61^{\circ} 31.43^{\prime} \mathrm{W}$ & 18.V.2012 & 8 \\
\hline GB22 & $16^{\circ} 30.57^{\prime} \mathrm{N}$ & $61^{\circ} 28.45^{\prime} \mathrm{W}$ & 19.V.2012 & 12 \\
\hline GB23 & $16^{\circ} 30.04^{\prime} \mathrm{N}$ & $61^{\circ} 28.79^{\prime} \mathrm{W}$ & 19.V.2012 & 16 \\
\hline GB26 & $16^{\circ} 22.28^{\prime} \mathrm{N}$ & $61^{\circ} 38.14^{\prime} \mathrm{W}$ & 23.V.2012 & 29 \\
\hline GB30 & $16^{\circ} 10.97^{\prime} \mathrm{N}$ & $61^{\circ} 32.41^{\prime} \mathrm{W}$ & 25.V.2012 & 16 \\
\hline GB31 & $16^{\circ} 09.71^{\prime} \mathrm{N}$ & $61^{\circ} 07.73^{\prime} \mathrm{W}$ & 26.V.2012 & 15 \\
\hline GB32 & $16^{\circ} 10.54^{\prime} \mathrm{N}$ & $61^{\circ} 06.51^{\prime} \mathrm{W}$ & 26.V.2012 & 4 \\
\hline GD20 & $16^{\circ} 15.54^{\prime} \mathrm{N}$ & $61^{\circ} 48.71^{\prime} \mathrm{W}$ & 12.V.2012 & 35 \\
\hline GD33 & $16^{\circ} 24^{\prime} \mathrm{N}$ & $61^{\circ} 33^{\prime} \mathrm{W}$ & 16.V.2012 & 130 \\
\hline GD66 & $16^{\circ} 08.17^{\prime} \mathrm{N}$ & $61^{\circ} 17.32^{\prime} \mathrm{W}$ & 27.V.2012 & 33 \\
\hline GM03 & $16^{\circ} 16.17^{\prime} \mathrm{N}$ & $61^{\circ} 35.1^{\prime} \mathrm{W}$ & 3.V.2012 & $0-2$ \\
\hline GM05 & $16^{\circ} 16.5^{\prime} \mathrm{N}$ & $61^{\circ} 33.3^{\prime} \mathrm{W}$ & 4.V.2012 & $0.5-1$ \\
\hline GM06 & $16^{\circ} 09^{\prime} \mathrm{N}$ & $61^{\circ} 33.67^{\prime} \mathrm{W}$ & 5-6.V.2012 & $0-2$ \\
\hline GM07 & $16^{\circ} 10.45^{\prime} \mathrm{N}$ & $61^{\circ} 46.78^{\prime} \mathrm{W}$ & 7-8.V.2012 & $0-2$ \\
\hline GM08 & $16^{\circ} 07.57^{\prime} \mathrm{N}$ & $61^{\circ} 46.45^{\prime} \mathrm{W}$ & 8.V.2012 & $0-2$ \\
\hline GM10 & $16^{\circ} 12.53^{\prime} \mathrm{N}$ & $61^{\circ} 25.55^{\prime} \mathrm{W}$ & 10.V.2012 & $0-2$ \\
\hline GM11 & $16^{\circ} 11.97^{\prime} \mathrm{N}$ & $61^{\circ} 34.28 \mathrm{~W}$ & 11.V.2012 & $0-2$ \\
\hline GM12 & $16^{\circ} 12.7^{\prime} \mathrm{N}$ & $61^{\circ} 30.32^{\prime} \mathrm{W}$ & 11.V.2012 & 3 \\
\hline GM17 & $16^{\circ} 28.32^{\prime} \mathrm{N}$ & $61^{\circ} 30.88^{\prime} \mathrm{W}$ & 15.V.2012 & $0-2$ \\
\hline GM21 & $16^{\circ} 23.57^{\prime} \mathrm{N}$ & $61^{\circ} 31.37^{\prime} \mathrm{W}$ & 17.V.2012 & $0-2$ \\
\hline GM22 & $16^{\circ} 14.95^{\prime} \mathrm{N}$ & $61^{\circ} 10.83^{\prime} \mathrm{W}$ & 18.V.2012 & $0-2$ \\
\hline GM26 & $16^{\circ} 13.31^{\prime} \mathrm{N}$ & $61^{\circ} 32.89^{\prime} \mathrm{W}$ & 20.V.2012 & $0-2$ \\
\hline GM33 & $16^{\circ} 15.37^{\prime} \mathrm{N}$ & $61^{\circ} 11.92^{\prime} \mathrm{W}$ & 25.V.2012 & 6 \\
\hline GR03 & $16^{\circ} 11.8^{\prime} \mathrm{N}$ & $61^{\circ} 29.66^{\prime} \mathrm{W}$ & 3.V. 2012 & 6 \\
\hline GR12 & $16^{\circ} 22.9^{\prime} \mathrm{N}$ & $61^{\circ} 45.94^{\prime} \mathrm{W}$ & 8.V.2012 & 21 \\
\hline GR27 & $16^{\circ} 22.57^{\prime} \mathrm{N}$ & $61^{\circ} 31.74^{\prime} \mathrm{W}$ & 15.V.2012 & 8 \\
\hline GR31 & $16^{\circ} 23.26^{\prime} \mathrm{N}$ & $61^{\circ} 31.79^{\prime} \mathrm{W}$ & 17.V.2012 & 14 \\
\hline GR32 & $16^{\circ} 26.78^{\prime} \mathrm{N}$ & $61^{\circ} 32.41^{\prime} \mathrm{W}$ & 18.V.2012 & 16 \\
\hline
\end{tabular}

Not Megalobrachium mortenseni-Rodríguez et al. 2005: 550, pl. 1 A.

MATERIAL EXAMINED. - Guadeloupe. KARUBENTHOS, 2012, 1 ơ 4.4 × 4.2 mm, MNHN-IU-2013-5215; 1 sp., MNHN-IU-2013-5088, st. GR03, lot JL130; 1 ơ 2.9 × 2.8 mm, MNHN-IU-2013-7145, st. GB30, lot JL1389; 1 ○ $2.7 \times 2.7 \mathrm{~mm}, 1 \mathrm{sp}$. broken MNHN-IU-2013-5994, st. GB01, no JL number.

DiAGNOSIS. - Carapace eroded, with transverse ridges on branchial and posterior regions; supra-ocular and external orbital angles unarmed; no epibranchial spine. Carpus of cheliped with granular lobe on proximal half of anterior margin; posterior margin without teeth; dorsal surface with longitudinal rows of deep pits. Chela (palm and fingers) with deep longitudinal grooves on dorsal surface. Merus of ambulatory legs unarmed; carpus unarmed, with two crests on anterior margin; dactylus with five movable spines on posterior margin. Telson composed of seven plates.

REMARKS. - This is the first record of $M$. mortenseni from Guadeloupe Island.

The small male $(2.9 \times 2.8 \mathrm{~mm}$, st. GB30, MNHNIU-2013-7145) has the typical row of pits on the carpus of the cheliped, a characteristic of M. mortenseni. However, contrary to larger specimens, the lateral margins of the carapace are carinated and finely denticulated, and the transverse granulated ridges on the branchial regions 
of the carapace are very marked. These differences are probably size-related.

The illustration of $M$. mortenseni in Rodríguez et al. (2005: 550, pl. 1A) is in fact M. roseum (Rathbun, 1900). Megalobrachium mortenseni and the eastern Pacific $M$. erosum (Glassell, 1936), are considered geminate species (Haig 1962: 191).

Habitat. - Collected in Guadeloupe, in depths of 6 to $16 \mathrm{~m}$. Some specimens were found on sandy bottom with patches of coral and sea grass beds (Thalassia, Syringodium) (st. GB30).

DisTRIBUTION. - Western Atlantic: from Virgin Islands and Lesser Antilles (ICA, Guadeloupe; IOV, Margarita), Honduras, Panama, Colombia, Venezuela to São Paulo, Brazil.

\section{Megalobrachium poeyi (Guérin-Méneville, 1855)}

(Fig. 2B)

Porcellana poeyi Guérin-Méneville, 1855: pl. 2, fig. 4 (type locality: Cuba).

Megalobrachium granuliferum - Stimpson 1858: 228, nomen nudum; 1859: 76 (type locality: Virgin Islands, St Thomas, and Barbados). - Doflein 1899: 182 (Martinique).

Megalobrachium poeyi - Schmitt 1924a: 76 (Curaçao); 1924b: 90 (Pelican Island, Antigua and Barbuda); 1936: 375 (Aruba). - Haig 1962: 188 (Virgin Islands, Tobago). - Lira 1997: 108, fig. 31 (Margarita). — Lira et al. 2001: 58 (Coche, Margarita, Cubagua); 2012: 27 (La Tortuga). - Werding et al. 2003: 81, tab. 1 (Lesser Antilles). - Rodríguez et al. 2005: 551 (Margarita).

MATERIAL EXAMINED. - Guadeloupe. KARUBENTHOS, 2012, 1 ơ $3.5 \times 3.5 \mathrm{~mm}$, MNHN-IU-2013-5297, st. GM06, lot JL245; 1 ơ $3.5 \times 3.5 \mathrm{~mm}, \mathrm{MNHN}-$ IU-2013-5081, st. GM06, lot JL279b.

Diagnosis. - Carapace smooth with few granules, protogastric region elevated, lateral margins setiferous; supra-ocular and external orbital angles unarmed; no epibranchial spine. Carpus of cheliped with anterior margin straight, minutely serrated but without spines or teeth; posterior margin minutely serrated, with plumose setae; dorsal surface granulated, with two longitudinal ridges. Chela granulated, with two longitudinal ridges on dorsal surface; anterior margin with long plumose setae; gape of fingers with setae. Ambulatory legs heavily setose; dactylus with four movables spines on posterior margin. Telson composed of seven plates.
REMARKS. - This is the first record of $M$. poeyi from Guadeloupe Island.

The presence of abundant setation on the chelipeds and ambulatory legs is a reliable character to separate $M$. poeyi from $M$. roseum, a similar species found in the western Atlantic (see Rodríguez et al. 2005: 550, Pl. 1B, C). Megalobrachium poeyi and the eastern Pacific M. pacificum Gore \& Abele, 1974, are considered geminate species (Gore \& Abele 1974: 570; 1976: 17).

HabITAT. - Collected in the intertidal of "Îlet Fortune" during low tide, on rocks and coral rubble.

DistribUTION. - Western Atlantic: from eastern Florida, USA, Gulf of Mexico, Greater Antilles, Virgin Islands and Lesser Antilles (ICA, Pelican Island at Antigua and Barbuda, Guadeloupe, Martinique, Barbabos, Tobago; IOV, Coche, Margarita, Cubagua, Curaçao, Aruba), Panama, Colombia, Venezuela to Sáo Paulo, Brazil.

\section{Megalobrachium soriatum (Say, 1818)}

(Fig. 2C)

Porcellana soriata Say, 1818: 456 (type locality: St. Catherine's Island, Georgia). — Schmitt 1924b: 90 (Barbados).

Megalobrachium soriatum - Lira 1997: 102, fig. 29 (Margarita). - Lira et al. 2001: 56 (Margarita). - Werding et al. 2003: 81, tab. 1 (Lesser Antilles). — Rodríguez et al. 2005: 552 (Martinique).

MATERIAL EXAMINED. - Guadeloupe. KARUBENTHOS, 2012, 1 ơ $2.6 \times 2.8 \mathrm{~mm}$, MNHN-IU-2013-5083, st. GR12, lot JL434.

DIAGNOSIS. - Carapace areolated on gastric and branchial regions; lateral margin with three mesobranchial spinules; supra-ocular and external orbital angles unarmed; epibranchial region with subacute tubercle. Carpus of cheliped with blunt tooth on proximal half of anterior margin; posterior margin emarginated, dorsal surface with granular tubercles arranged in longitudinal rows. Palm with longitudinal rows of granular tubercles on dorsal surface, anterior margin with spinules and row of long plumose setae, gape of fingers without setae. Ambulatory legs setose; dactyl curved; with three movable spines on posterior margin. Telson composed of five plates.

REMARKS. - This is the first record of $M$. soriatum from Guadeloupe Island.

Megalobrachium soriatum and the eastern Pacific Megalobrachium tuberculipes (Lockington, 1878) differ only slightly in morphology, and are considered geminate species (Gore \& Abele 1976). In the western Atlantic, molecular data by Rodríguez et al. (2006) suggest the 
existence of a cryptic species under M. soriatum.

HABITAT. - Collected at depth of $21 \mathrm{~m}$, on rocky bottom with sessile organisms. Sometimes reported inside sponges (Haig 1956: 36; Williams 1984: 241).

DisTRIBUTION. - Western Atlantic: from North Carolina, USA, Gulf of Mexico, Lesser Antilles (ICA, Guadeloupe, Martinique, Barbados; IOV, Margarita), Panama, Colombia, to São Paulo, Brazil.

\section{Neopisosoma angustifrons (Benedict, 1901)} (Fig. 2D)

Pisosoma angustifrons Benedict, 1901: 135, pl. 3, fig. 6 (type locality: Trinidad). — Schmitt 1924a: 74 (Curaçao); 1936: 374 (Bonaire). — Monod 1939: 559 (Guadeloupe). - Haig 1956: 15 (Cubagua, La Tortuga). — Rodríguez 1980: 214, pl. 2 (Margarita). — Lira 1997: 54, fig. 14 (Margarita).

Neopisosoma angustifrons - Haig 1962: 181 (Virgin Islands). - Werding 1986: 162 (Saba, St Eustatius, Grenada, Trinidad, Bonaire, Curaçao, Aruba). - Lira 1997: 54, fig. 14 (Margarita). - Werding et al. 2003: 81, tab. 1 (Lesser Antilles). - Rodríguez et al. 2005: 553 (Cubagua).

MATERIAL EXAMINED. - Guadeloupe. KARUBENTHOS, 2012, 1 ơ $3.2 \times 3.6$ mm, MNHN-IU-2013-5588, st. GM08, lot JL400.

DIAGNOSIS. - Carapace sub-oval, granulated; supra-ocular and external orbital angles unarmed; epibranchial region unarmed; pterygostomian flap entire but incomplete, mesobranchial portion occupied by membrane. Chelipeds thick, completely covered with rounded granules but without setae; carpus with five obtuse teeth on anterior margin; posterior margin convex, granulated; dorsal surface of palm with granules arranged in longitudinal rows; anterior margin granulated. Ambulatory legs short, robust, without setation; merus and carpus unarmed; dactylus curved, with three movable spines on posterior margin. Telson composed of five plates.

REMARKS. - This species is easily recognizable by the thick chelipeds, completely covered with rounded granules but no setae. The eastern Pacific geminate of $N$. angustifrons is $N$. dohenyi Haig, 1960 (see Haig 1960: 131).

HАВІтAT. - Collected in the lower intertidal region at low tide, on rocks and coral rubble.

Distribution. - Western Atlantic: from Florida, USA, Bahamas, Greater Antilles, Virgin Islands and Lesser Antilles (ICA, Saba, St Eustatius, Guadeloupe, Trinidad;
IOV, Margarita, Cubagua, La Tortuga, Bonaire, Curaçao, Aruba), Mexico to Venezuela.

\section{Neopisosoma curacaoense (Schmitt, 1924)}

(Fig. 2E)

Pisosoma curaçaoensis Schmitt, 1924a: 75, pl. 8, figs 1-3, (type locality: Lesser Antilles, Curaçao); 1936: 374 (Bonaire)

Pisosoma curacaoense - Haig 1956: 15 (La Tortuga, Aruba).

Neopisosoma curacaoense - Haig 1962: 181 (Virgin Islands). - Scelzo 1984: 374 (Cubagua). — Werding 1986: 162 (Saba, St Martin, St Eustatius, Grenada, Aruba). - Werding et al. 2003: 81, tab. 1 (Lesser Antilles).

MATERIAL EXAMINED. - Guadeloupe. KARUBENTHOS, 2012, 1 우 $4.2 \times 4.0 \mathrm{~mm}$, MNHN-IU-2013-5359, st. GM08, lot JL399.

DiAGNOSIs. - Carapace subquadrate, slightly rugose; lateral margins feebly carinated; supra-ocular and external orbital angles unarmed; epibranchial region unarmed; pterygostomian flap entire but incomplete, mesobranchial portion occupied by a membrane. Carpus of cheliped with four blunt large teeth and one or two smaller distal teeth on anterior margin; posterior margin unarmed, with cotton-like setation on distal third; dorsal surface with three longitudinal ridges. Dorsal surface of chela with two longitudinal ridges on inner half; outer half, including fixed finger, covered with cotton-like setation; gape of fingers without setae. Ambulatory legs densely covered on anterior margins with cotton-like setation; merus and carpus unarmed; dactylus curved, with four movable spines on posterior margin. Telson composed of five-seven plates.

REMARKS. - This is the first record of $N$. curacaoense from Guadeloupe Island.

This species is remarkable in having the cotton-like setation on the chelipeds and ambulatory legs, a character unique in the western Atlantic Neopisosoma species (see key in Werding 1986).

HabitaT. - Collected in the lower intertidal region at low tide, on rocks and coral rubble.

Distribution. - Western Atlantic: Bahamas, Greater Antilles, Virgin Islands and Lesser Antilles (ICA, Saba, St Martin, St Eustatius, Guadeloupe, Grenada; IOV, Cubagua, La Tortuga, Bonaire, Curaçao, Aruba), to Mexico (but see remarks in Rodríguez et al. 2005 for this country). 


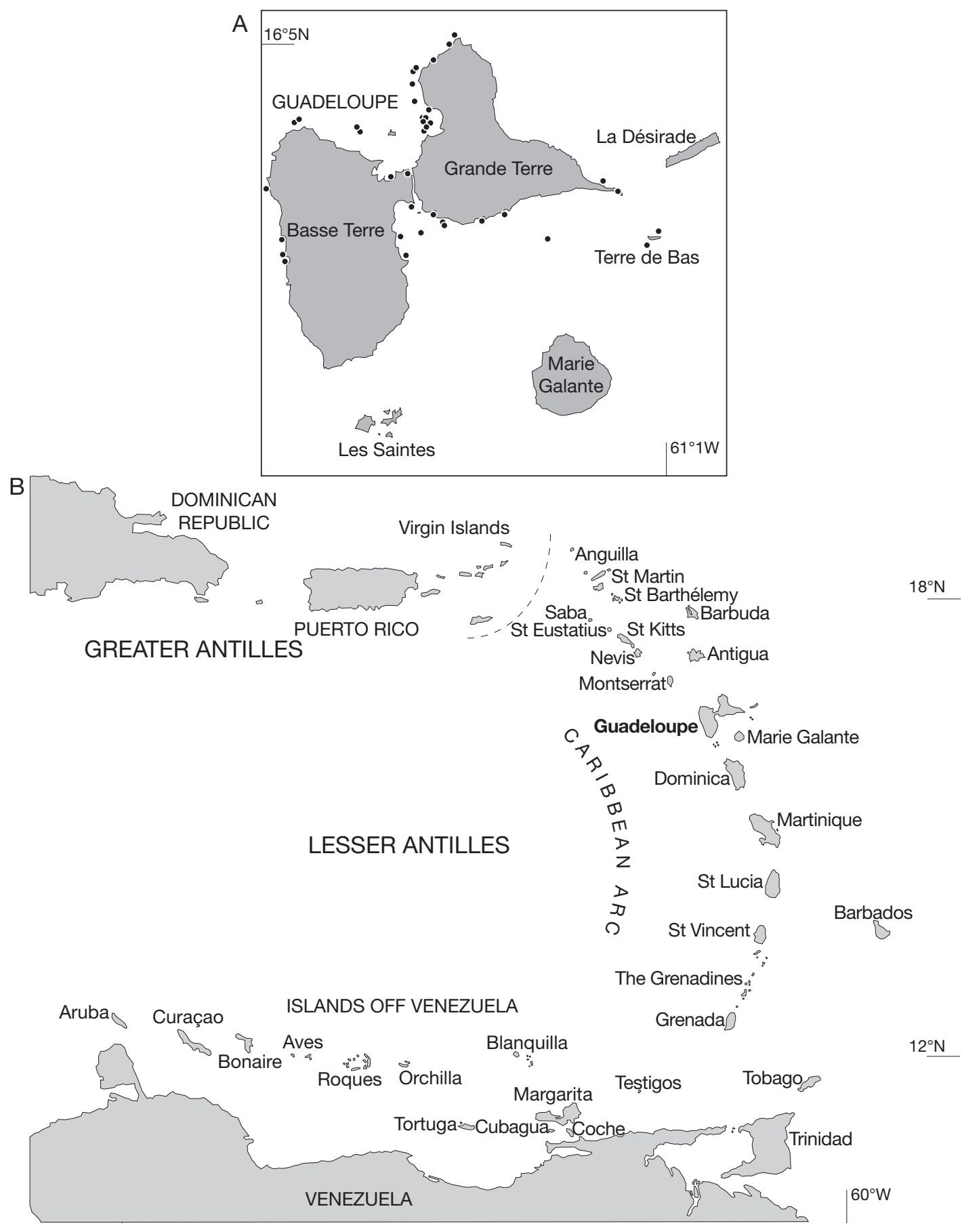

FIG. 1. - A, Map of Guadeloupe and surroundings Islands. The 37 stations, where porcellanid crabs were collected, are situated around Grande Terre, Basse Terre, and Terre de Bas, as indicated by the black dots. A detailed list of stations is presented separately in Table 1; B, Location of Guadeloupe Island in the Lesser Antilles, including the Islands of the Caribbean arc and the Islands situated off Venezuela. 


\section{Pachycheles pilosus (H. Milne Edwards, 1837)} (Fig. 2F)

Porcellana pilosa H. Milne Edwards, 1837: 225 (type locality: Charleston, South Carolina). - A. MilneEdwards \& Bouvier 1923: 294 (St Thomas).

Pachychelespilosus - Schmitt 1924a: 76 (Curaçao); 1924b: 90 (Barbados); 1936: 375 (Aruba, Bonaire). — Monod 1939: 559 (Guadeloupe). — Haig 1956: 11 (Tobago, Aruba). - Scelzo \& Varela 1988: 39, fig. 2 (La Blanquilla). - Werding et al. 2003: 81, tab. 1 (Lesser Antilles). - Rodríguez et al. 2005: 556 (La Tortuga). — Lira et al. 2007: 38 (La Blanquilla, La Tortuga, Aves).

MATERIAL EXAMINED. — Guadeloupe. KARUBENTHOS, 2012, 1 \% $3.8 \times 4.0 \mathrm{~mm}$, MNHN-IU-2013-4924, st. GM07, lot JL357; 1 ㅇ ov $5.0 \times 5.4 \mathrm{~mm}$, MNHNIU-2013-5293, st. GM10, lot JL561.

DiAGNOSIS. - Carapace entirely covered with short and stiff bristles more or less arranged in transverse rows; supraocular angle unarmed, external orbital angle with one spine, epibranchial region unarmed; pterygostomian flap of carapace broken up into two main pieces separated by membranous interspace. Chelipeds thickly covered with long and stiff bristles on dorsal face; carpus with three large spines on anterior margin, posterior margin unarmed, dorsal surface with seven or eight blunt spines on proximal outer half; anterior margin of palm with row of 10 or 11 spines, continuing onto fixed finger; gape of fingers with a few sparse setae. Ambulatory legs with stiff bristles on anterior margins; merus unarmed; carpus with two (legs 1-2) or 1 (leg 3) anterodistal spine; dactylus curved, with three movable spines on posterior margin. Telson composed of five plates.

REMARKS. - This species is distinguished from all others western Atlantic species by the numerous stiff bristles which cover the carapace, chelipeds and ambulatory legs (see key in Lira et al. 2007).

HAвітAт. - Collected in the low intertidal region at low tide, on rocks and coral rubble.

DisTRibution. - Western Atlantic: from South Carolina, USA, Bahamas, Greater Antilles, Virgin Islands and Lesser Antilles (ICA, Guadeloupe, Barbados, Tobago; IOV, La Blanquilla, La Tortuga, Aves, Bonaire, Curaçao, Aruba), Mexico, Colombia, to Venezuela.

\section{Parapetrolisthes tortugensis (Glassell, 1945)} (Fig. 2G)

Petrolisthes tortugensis Glassell, 1945: 228, fig. 2 (type locality: Tortugas, Florida). — Haig 1956: 22 (La Tortuga).
Parapetrolisthes tortugensis - Haig 1962: 174 (Virgin Islands). - Werding et al. 2003: 81, table 1 (Lesser Antilles).

MATERIAL EXAMINED. - Guadeloupe. KARUBENTHOS, 2012, 1 o $4.6 \times 4.3 \mathrm{~mm}$, MNHN-IU-2013-5590, st. GB21, lot JL1097.

Diagnosis. - Carapace with transverse setiferous striae; front bluntly triangular bearing short spines on lateral and distal margins; supra-ocular angle with one acute spine, external orbital angle with one short spine; one epibranchial spine; mesobranchial region with one dorsal spine and two lateral marginal spines. Cheliped long, about 2.5 times carapace length; carpus with four sharp spines on anterior margin, posterior margin with row of six inwardly curved spines, dorsal face with setiferous squamae and longitudinal row of two median spines proximally. Chelae with a row of inwardly curved spines on posterior margin continued on dactyl; anterior margin with double row of inwardly curved spines continued on fixed finger; palm granulated on dorsal surface, ventral face with oblique ridges; fingers with setae on gape, tips spoon-shaped. Merus of ambulatory legs with row of five-eight spines on anterior margin; carpus with one anterodistal spine (leg 1) or unarmed (leg 2-3); dactylus with four movable spines on posterior margin. Telson composed of seven plates.

REMARKS. - This is the first record of $P$. tortugensis from Guadeloupe Island.

Parapetrolisthes tortugensis is easily differentiated from all the others porcelain crabs of the Western Atlantic by the spoon-shaped aspect of the finger tips of the chela (see Werding 1982, fig. 2).

HABITAT. - A sole specimen was collected by brushing coral rubble and stones at a depth of $8 \mathrm{~m}$. Werding (1982) indicated that $P$. tortugensis was not collected in the Islas del Rosario at depths of less than $9 \mathrm{~m}$, and seemed to prefer deeper areas. The maximum collection depth of the species reported by Felder et al. (2009) was $54 \mathrm{~m}$.

Distribution. - Western Atlantic: from Florida, USA, Bahamas, Virgin Islands and Lesser Antilles (ICA, Guadeloupe; IOV, La Tortuga), Mexico (Campeche Bank), to Colombia.

\section{Petrolisthes amoenus (Guérin-Méneville, 1855)} (Fig. 3A)

Porcellana amoena Guérin-Méneville, 1855, pl. 2, fig. 2 (type locality: Cuba). 


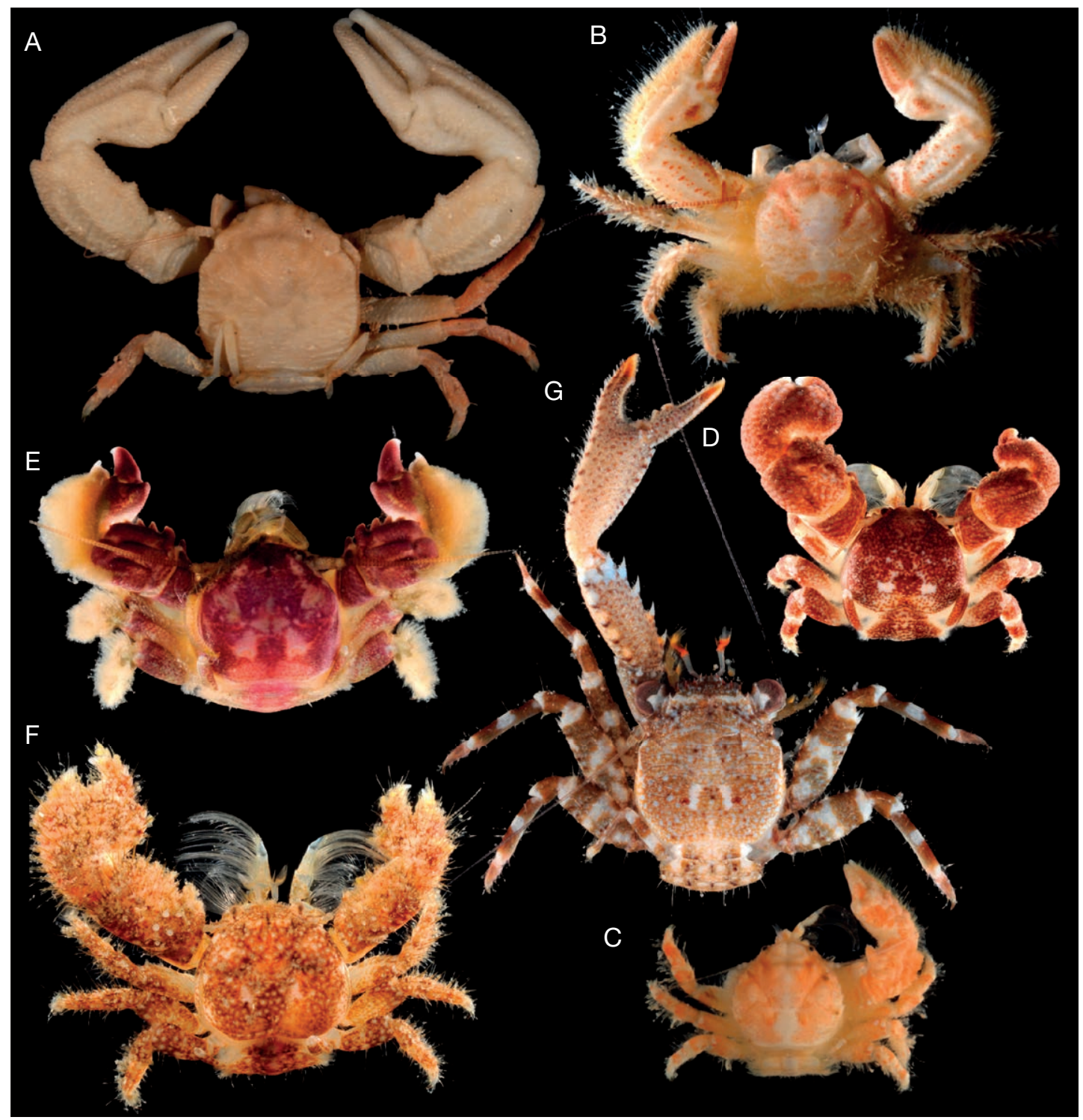

FIG. 2. - A, Megalobrachium mortenseni Haig, 1962, 1 ơ $4.4 \times 4.2$ mm, MNHN-IU-2013-5215, st. GR03 (preserved specimen); B, Megalobrachium poeyi (Guérin-Méneville, 1855), 1 ơ 3.5 × 3.5 mm, MNHN-IU-2013-5297, st. GM06; C, Megalobrachium soriatum (Say, 1818), 1 ơ $2.6 \times 2.8$ mm, MNHN-IU-2013-5083 (preserved specimen), st. GR12; D, Neopisosoma angustifrons (Benedict, 1901$), 10^{7}$ $3.2 \times 3.6$ mm, MNHN-IU-2013-5588, st. GM08; E, Neopisosoma curacaoense (Schmitt, 1924), 1 $4.2 \times 4.0$ mm, MNHN-IU-2013-5359, st. GM08; F, Pachycheles pilosus (H. Milne Edwards, 1837), 1 ㅇ $3.8 \times 4.0$ mm, MNHN-IU-2013-4924. st. GM07; G, Parapetrolisthes tortugensis (Glassell, 1945), 1 ơ $4.6 \times 4.3 \mathrm{~mm}$, MNHN-IU-2013-5590, st. GB21. Magnifications are about $\times 5$ for each species.

Petrolisthes amoenus - Haig 1956: 25 (Tobago); 1962: 177 (Virgin Islands, Tobago). — Schmitt 1924a: 74 (Curaçao); 1924b: 89 (Barbados); 1936: 374 (Bonaire). - Chace 1956: 152 (Los Roques). — Gore 1974:
707, fig. 3 (Antigua, St Lucia, Grenada). - Werding et al. 2003: 81, tab. 1 (Lesser Antilles). - Rodríguez et al. 2005: 559 (Cubagua). - Lira et al. 2012: 27 (La Tortuga). 
MATERIAL EXAMINED. - Guadeloupe. KARUBENTHOS, 2012, 1 sp. MNHN-IU-2013-4783, st. GB01, no JL number; 1 sp. MNHN-IU-2013-5214, 1 sp. MNHN-IU-2013-5442, st. GB02, lot JL190; 1 sp. MNHN-IU-2013-5091, st. GB02, lot JL193; 1 sp. MNHN-IU-2013-5089, st. GB02, lot JL199; 4 sp. MNHN-IU-2013-6806, st. GB06, lot JL452; 1 ơ 6.8 × 6.5 mm, MNHN-IU-2013-5294, st. GB06, lot JL459; 4 우 우 3.6 3.4-7.0 $6.9 \mathrm{~mm}$, MNHN-IU-2013-5078, st. GB09, lot JL565; 1 ㅇ ov. $5.8 \times 5.7 \mathrm{~mm}, \mathrm{MNHN}-$ IU-2013-5424, st. GB15, lot JL833; 1 sp. about $5.0 \times$ 4.7 mm, MNHN-IU-2013-5357, st. GB15, lot JL869; 1 sp., MNHN-IU-2013-5993, st. GB15, lot JL280b; 1 sp. MNHN-IU-2013-5594, st. GB18, lot JL956; 6 sp. MNHN-IU-2013-5211, st. GB19, lot JL985; 1 sp. MNHN-IU-2013-5589, st. GB20, lot JL1067b; 10 sp. MNHN-IU-2013-6791, st. GB20, lot JL1069; 1 sp. MNHN-IU-2013-7149, st. GB20, lot JL1092; 8 sp. MNHN-IU-2013-5075, 1 sp. MNHN-IU-2013-5079, st. GB22, lot JL1113; 4 juv. MNHN-IU-2013-5426, st. GB23, lot JL1119; 1 o ov., MNHN-IU-2013-5356, st. GB26, lot JL1272; 7 sp., MNHN-IU-2013-6811, st. GB31, lot JL1430; 2 o" o" $6.1 \times 5.9-6.5 \times 6.1 \mathrm{~mm}$, MNHN-IU-2013-5295, st. GD66, lot JL1439; 12 juv. MNHN-IU-2013-5052, st. GM12, lot JL652; 1 juv. MNHN-IU-2013-5358, st. GM21, lot JL942; 1 o ov. $5.0 \times 4.7 \mathrm{~mm}$, MNHN-IU-2013-7152, st. GR12, lot JL443; 1 o $4.2 \times 3.8-4.9 \times 4.6 \mathrm{~mm}, 1$ \% $3.6 \times 3.2 \mathrm{~mm}$, MNHN-IU-2013-6797, st. GR32, lot JL1058.

DiAGNOSIS. - Carapace almost smooth, without setae or sparsely setose; front subtriangular, with numerous spinules on margins; supra-ocular and external orbital angles each armed with spine; one epibranchial spine, two (rarely one or three) mesobranchial spines. Carpus of cheliped with four or five broad, serrated teeth on anterior margin and with five or six inwardly curved spines on posterior margin. Palm of cheliped with long feathered setae and row of forwardly directed spines on anterior margin; gape of fingers with short pubescence covering proximal half of dactylus and proximal angle of pollex (not visible from above). Meri of ambulatory legs each with row of six or seven (legs 1-2) and five (leg 3) spines on anterior margin; carpus with one anterodistal spine (leg 1), unarmed or one spine (leg 2) or unarmed (leg 3); dactylus with three movable spines on posterior margin. Telson composed of seven plates.

REMARKS. - This is the first record of P. amoenus from Guadeloupe Island.

This was the most commonly collected porcellanid species during KARUBENTHOS fieldwork. The large series of specimens examined are overall similar to those already described and illustrated by Gore (1974: fig. 3) from other Lesser Antilles (Antigua, St Lucia, Grenada). Live coloration (Fig. 3A) turned to cream background scattered with pink spots after preservation. Other colorations useful to quickly sort preserved specimens of this species are: 1) two white rings separated by a narrow brown median line on the proximal and distal portions of the propodus of each ambulatory leg; and 2) a remarkable dark pink spot in the middle portion of the propodus of the third maxilliped.

HABITAT. - Mostly collected by brushing coral heads and rubble in the outer reef slope at depths of $6-45 \mathrm{~m}$ (st. GB); rarely collected with dredge (st. GD66, $33 \mathrm{~m}$ ) or on coral bottom in shallow waters, at depths of 2-3 m (st. GM12, GM21). In other islands of the Lesser Antilles, Gore (1974) indicated that $P$. amoenus was collected at depths of 13-22 m.

Distribution. - Western Atlantic: from Florida Straits, USA, Greater Antilles, Virgin Islands and Lesser Antilles (ICA, Antigua, Guadeloupe, St Lucia, Barbados, Grenada, Tobago; IOV, Cubagua, La Tortuga, Los Roques, Bonaire, Curaçao), Mexico, Colombia, Venezuela, to Alagôas and Bahia, Brazil.

\section{Petrolisthes armatus (Gibbes, 1850)}

(Fig. 3B, C)

Porcellana armata Gibbes, 1850: 190 (type locality: Florida).

Petrolisthes armatus - Stimpson 1859: 73 (Virgin Islands). — Rathbun 1919: 11 (Curaçao). - Haig 1962: 178 (Virgin Islands). — Gore 1974: 709 (Trinidad). - Rodríguez 1980: 217, pl. 3 (Margarita). - Scelzo \& Varela 1988: 40 (La Blanquilla). — Lira 1997: 91, fig. 26 (Margarita). - Hernández et al. 1999: 27, tab. 1 (Margarita). - Werding et al. 2003: 81, tab. 1 (Lesser Antilles). - Rodríguez et al. 2005: 560 (Margarita, Cubagua). — Lira et al. 2012: 26 (La Tortuga).

MATERIAL EXAMINED. - Guadeloupe. KARUBENTHOS, 2012, 2 sp., MNHN-IU-2013-5074, st. GM03, lot JL81; 1 o ov. $8.4 \times 7.9 \mathrm{~mm}$, MNHN-IU-2013-5082, st. GM03, lot JL82; 1 sp., MNHN-IU-2013-6796, st. GM03, st. JL114; 6 sp. $5.3 \times 4.7-8.1 \times 7.9 \mathrm{~mm}$, MNHN-IU-2013-5084, st. GM03, lot JL115; 1 sp., MNHN-IU-2013-5213, st. GM26, lot JL1197; 1 o" $7.0 \times 6.5 \mathrm{~mm}$, MNHN-IU-2013-5085, st. GM05, lot JL187; 1 o $6.8 \times 6.2 \mathrm{~mm}$, MNHN-IU-2013-6859, st. GM05, lot JL187.

Diagnosis. - Carapace rugose with protogastric ridge elevated; supra-ocular and external orbital angles unarmed, one acute epibranchial spine. Carpus of cheliped anteriorly with three low distant, spine-tipped teeth minutely denticulated on edges; posterior margin 


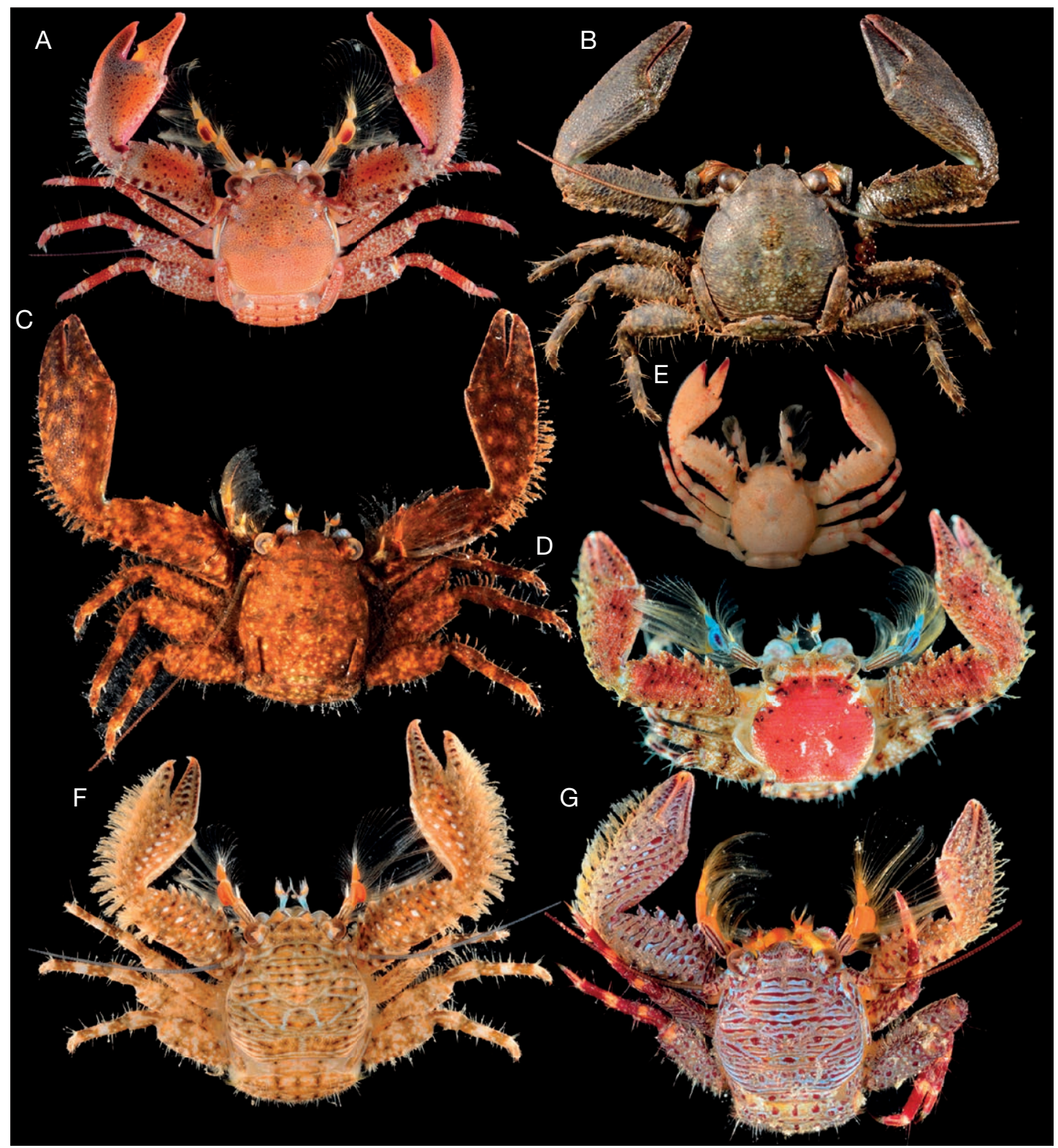

FIG. 3. - A, Petrolisthes amoenus (Guérin-Méneville, 1955), $1 \mathrm{sp}$. about $5.0 \times 4.7 \mathrm{~mm}$, MNHN-IU-2013-5357, st. GB15; Petrolisthes armatus (Gibbes, 1850); B, 1 \% ov. $8.4 \times 7.9$ mm, MNHN-IU-2013-5082, st. GM03; C, 1 ơ $7.0 \times 6.5$ mm, MNHN-IU-2013-5085, st. GM05; D, Petrolisthes caribensis Werding, 1983, 1 o $5.5 \times 5.3$ mm, MNHN-IU-2013-4978, st. GB32; E, Petrolisthes dissimulatus Gore, 1983,1 웅 $3.7 \times 3.5$ mm, MNHN-IU-2013-7154, st. GM07; Petrolisthes galathinus; F, 1 \% $7.2 \times 7.2$ mm, MNHN-IU-2013-6808, st. GM11; G, color variety of $P$. galathinus (Bosc, 1802) "White Teeth 2", st. GM10, lot JL573, photo only, specimen not retrieved. Magnification is about $\times 3$ for each species.

setiferous, with three-five inwardly curved spines; dorsal surface transversally rugose. Dorsal surface of chela granulated; anterior margin of palm setiferous, usually with row of six-ten forwardly curved spines; gape of fingers with cotton-like setation (not visible from dorsal view). Ambulatory legs with or without plumose setae 
on anterior margins of merus and carpus; merus with three or four spines on anterior margin; carpus with one anterodistal spine (legs 1-2) or unarmed (leg 3); dactylus with three movable spines on posterior margin. Telson composed of seven plates

REMARKS. - This is the first record of $P$. armatus from Guadeloupe Island.

Rodríguez et al. (2005) indicated that $P$. armatus is the most widespread species in the western Atlantic, and also considered its distribution to include the eastern Pacific and eastern Atlantic. These authors also mentioned that populations of $P$. armatus show considerable morphological variations, and that this taxon might actually be a complex of species. The following morphological variations were observed in the material examined: the armature on the anterior margin of the palm of the chela is sometimes reduced to one or two very low spines, with the setation of this margin sometimes absent; and the setation of the anterior margins of the merus and carpus of the ambulatory legs can be absent. The color patterns of the carapace, chelae and ambulatory legs, were also observed to vary, such as in specimens collected at st. GM03 and st. GM05 (compare Fig. 3B, C), although the color patterns of the antennule (blue and orange) and dactylus of the third maxilliped (brown and yellow) are constant.

Habitat. - Collected in the intertidal region at low tide, on eutrophic shores with mud and coral rubble (GM03) and in mangrove (GM05). A few specimens from GM03, a station obviously polluted, show unilateral morphological abnormalities on a single chela. A similar case of malformation has been documented by Lira $e t a l$. (2003) for Pachycheles serratus.

DistribUTiOn. - Western and eastern Atlantic; eastern Pacific. Widespread in western Atlantic: from Connecticut, USA, Bermudas, Bahamas, Greater Antilles, Virgin Islands and Lesser Antilles (ICA, Guadeloupe, Trinidad; IOV, Margarita, Cubagua, La Blanquilla, La Tortuga, Curaçao), to Santa Catarina, Brazil.

\section{Petrolisthes caribensis Werding, 1983}

(Fig. 3D)

Petrolisthes caribensis Werding, 1983: 411, figs 1, 4 (type locality: Rosario Islands, Colombia). - Werding et al. 2003: 81, tab. 1 (Lesser Antilles).

MATERIAL EXAMINED. - Guadeloupe. KARUBENTHOS, 2012, 1 \% ov $4.1 \times 3.8 \mathrm{~mm}$, MNHN-IU-2013-5212, st. GB02, lot JL200; 1 o' juv. $3.1 \times 2.7 \mathrm{~mm}, \mathrm{MNHN}-$ IU-2013-7153, st. GB30, lot JL1389; 1 ơ $5.5 \times 5.3$ mm, MNHN-IU-2013-4978, st. GB32, lot JL1461; 2 sp. MNHN-IU-2013-5296, st. GB32, lot JL1424.
DiAGNOSIS. - Carapace with strong, transverse, setiferous striae; supra-ocular and external orbital angles armed with one spine; one epibranchial spine; front sinuously triangular, with minute spines on margins. Carpus of cheliped anteriorly with four large pointed teeth serrated on edges; posterior margin with five or six forwardly curved sharp spines; dorsal face with transverse striae. Palm striated on dorsal surface; anterior margin setiferous, serrated (extended onto fixed finger), with parallel row of forwardly curved spines on antero-dorsal margin (not extended onto fixed finger); posterior margin of palm with one or two dorsodistal spines; gape of fingers setiferous, not visible from dorsal view. Ambulatory legs weakly setiferous on anterior margins; merus with row of four-eight spines on anterior margin; carpus with one anterodistal spine; dactylus with four movable spines on posterior margin. Telson composed of seven plates.

REMARKS. - This is the first record of P. caribensis from Guadeloupe Island.

Petrolisthes caribensis belongs to the P. galathinus complex of species. It is distinctive by the typical carmine background color with symmetrical white patches on the carapace (Werding 1983: 412). In addition, in the specimens examined, the third maxilliped has remarkable red longitudinal stripes on the carpus, a bright sky blue color on the propodus and dactylus, and a darker blue patch in the middle of the propodus (see Fig. 3D). There is also a longitudinal red stripe pattern on the carpus and propodus of each ambulatory leg. The bright carmine background color of the carapace can be sometimes replaced by a duller maroon-green color (unpublished color photograph, com. pers. A. Hiller), but the color pattern of the third maxilliped and ambulatory legs appears to be constant. The specimen of $P$. caribensis from Panama illustrated in color by Rodríguez et al. (2005: 550, pl. 1G) is obviously erroneously labeled because it shows the typical coloration of $P$. galathinus. More detailed color documentation of species of the $P$. galathinus complex can be viewed at the link provided by Hiller et al. (2006: 549, http://www.uni-giessen.de/porcellanidae/). This includes $P$. caribensis with typical carmine color morph and a color variation named $P$. caribensis "Blue" which, according to Hiller et al. (2006) probably belongs to a distinct undescribed species.

When no live coloration is available, $P$. caribensis can be confused with $P$. galathinus, both sharing many morphological characters (see Werding 1983: 408, tab. 1). The best character to distinguish these two closely similar species is the number of movable spines on posterior margin of the dactylus of the ambulatory legs: three spines in P. galathinus instead of four spines in P. caribensis.

HABITAT. - Coral bottoms. Collected by brushing coral heads and rubble in shallow waters $(4 \mathrm{~m})$ and on outer reef slope $(11 \mathrm{~m})$. 
Distribution. - Western Atlantic: from Florida Keys, Greater Antilles, Lesser Antilles (Werding et al. 2003; com. pers. A. Hiller; ICA, St Martin, Guadeloupe, Martinique; IOV, Bonaire, Curaçao), Mexico, Belize, Panama, Colombia, to Venezuela.

\section{Petrolisthes dissimulatus Gore, 1983}

(Fig. 3E)

Petrolisthes dissimulatus Gore, 1983: 94, figs 2-4 (type locality: St John, Virgin Islands; Barbados, Curaçao). - Werding et al. 2003: 81, tab. 1 (Lesser Antilles). — Rodríguez et al. 2005: 561 (Martinique).

Petrolisthes marginatus - Schmitt 1924a: 73 (Curaçao); 1924b: 88 (Barbados). — Haig 1956: 17, 26 (in part, Curaçao); 1962: 176 (in part, Virgin Islands). Not P. marginatus Stimpson, 1859 .

MATERIAL EXAMINED. - Guadeloupe. KARUBENTHOS, 2012, 1 우 $3.7 \times 3.5 \mathrm{~mm}$, MNHN-IU-2013-7154, st. GM07, lot JL368.

DiAGNOSIS. - Carapace smooth, faintly pubescent; frontal region trilobate, median lobe rounded and denticulated, lateral lobe rectangularly rounded, serrated; supra-ocular angle serrated, without spine, external orbital angle with small spine, epibranchial region with two spines. Carpus of cheliped with four (right) or five (left) serrated teeth on anterior margin and six-eight inwardly curved spines on posterior margin; dorsal surface with median row of seven or eight squamous tubercles. Dorsal surface of palm with fine pubescence on outer half and longitudinal crest of low granules between dactylar and carpal articulations; anterior margin with row of low forwardly directed spines; posterior margin with two dorsodistal curved spines; gape of fingers with a few short setae but not obviously pubescent. Merus of ambulatory legs with row of four-six spines on anterior margin; carpus with one anterodistal spine (legs 1-2) or unarmed (leg 3); dactylus with three movable spines on posterior margin. Telson composed of seven plates.

REMARKS. - This is the first record of $P$. dissimulatus from Guadeloupe Island.

The present small sole specimen was mixed with a lot of several species of Paguridae at st. GM07. It is illustrated on Fig. 3E but its live coloration was not recorded. Gore (1983: 98) mentioned a pink coloration on the live specimens examined by Benedict (1901). Morphological characters of the present Guadeloupe specimen overall fit those given and illustrated by Gore (1983: figs 2, 3 ) for the description of $P$. dissimulatus, especially the median longitudinal crests on the dorsal surfaces of the carpus and palm of the chelipeds, and the presence of two epibranchial spines on the carapace. Petrolisthes marginatus is closely similar to $P$. dissimulatus but it differs from the latter species in having a single epibranchial spine instead of two.

Habitat. - Collected in the intertidal region at low tide among rocks and coral rubble.

Distribution. - Western Atlantic: from Greater Antilles, Virgin Island and Lesser Antilles (ICA, Guadeloupe, Martinique, Barbados; IOV, Curaçao), Colombia, to Venezuela.

\section{Petrolisthes galathinus (Bosc, 1802)}

(Fig. 3F, G)

Porcellana galathina Bosc, 1802: 231-233, pl. 6, fig. 2 (type locality: unknown).

Petrolisthes galatinus - Nobili 1898: 2 (St Thomas, Virgin Islands)

Petrolisthes galathinus - Schmitt 1924b: 88 (Barbados); 1936: 374 (Aruba, Bonaire). — Rathbun 1919: 11 (Curaçao). - Chace 1956: 152 (Los Roques). - Haig 1956: 24 (Trinidad, Cubagua); 1962: 175 (Virgin Islands, Tobago). — Gore 1974: 715 (Guadeloupe). — Rodríguez 1980: 217, pl. 5 (Margarita). - Lira 1997: 95, fig. 27 (Margarita). - Hernández et al. 1999: 27, tab. 1 (Margarita). - Werding et al. 2003: 81, tab. 1 (Lesser Antilles). - Rodríguez et al. 2005: 560 (Margarita, Cubagua). — Lira et al. 2012: 26, fig. 3C (La Tortuga).

MATERIAL EXAMINED. - Guadeloupe. KARUBENTHOS, 2012, 1 ơ $7.9 \times 7.9 \mathrm{~mm}$, MNHN-IU-2013-5087, 1 ov. $6.0 \times 6.0 \mathrm{~mm}, \mathrm{MNHN}-\mathrm{IU}-2013-6861,3 \mathrm{sp}$., MNHN-IU-2013-5216, st. GM06, lot JL248; 1 o" $9.0 \times 9.0 \mathrm{~mm}, \mathrm{MNHN}-\mathrm{IU}-2013-6807$, st. GM06, lot JL293; 1 sp., MNHN-IU-2013-5086, st. GM06, lot JL294, 1 sp., MNHN-IU-2013-5090, st. GM06, lot JL295; 2 o o $^{7} 5.5 \times 5.5-8.2 \times 8.0 \mathrm{~mm}, 1$ \% $7.4 \times$ 7.3 mm, MNHN-IU-2013-4979, st. GM06, lot JL279; $1 \mathrm{sp.} \mathrm{MNHN-IU-2013-5592,} \mathrm{st.} \mathrm{GM06,} \mathrm{no} \mathrm{JL} \mathrm{number;}$ 1 9 $7.2 \times 7.2 \mathrm{~mm}, \mathrm{MNHN}-\mathrm{IU}-2013-6808$, st. GM11, lot J 692; 1 \%, MNHN-IU-2013-4977, st. GM11, lot JL692; 20 sp. $4.4 \times 4.4-6.6 \times 6.6 \mathrm{~mm}, \mathrm{MNHN}-$ IU-2013-5060, st. GM11, lot JL692; 1 o" $4.8 \times 4.5 \mathrm{~mm}$, MNHN-IU-2013-7155, st. GB01, lot JL103b.

AdDitional obserVation. - Guadeloupe, KARUBENTHOS, 2012, 1 sp. st. GM10, lot JL573, photo only (Fig. 3G), specimen not retrieved. Color variety of P. galathinus "White Teeth 2" in Hiller et al. (2006: 556, tab. 3 and http://www.uni-giessen.de/porcellanidae/). 
REMARKS. - The diagnosis of this species is similar to that of $P$. caribensis, another species of the $P$. galathinus complex. The only diagnostic difference is that in P. galathinus the posterior margin of the palm lacks any distinct spines whereas one or two dorsodistal spines are present in P. caribensis; and the dactylus of the ambulatory legs has three movable spines on the posterior margin, whereas there are four spines in P. caribensis. The two species can also be easily separated when live coloration is available (compare Figs. 3D and 3F, G).

The P. galathinus complex currently includes six species in the southern Caribbean: P. bolivarensis Werding $\&$ Kraus, 2003, P. caribensis, P. columbiensis Werding, 1983, P. galathinus, P. rosariensis Werding, 1978, and P. sanmartini Werding \& Hiller, 2002. Werding (1983: 408 tab. 1) and Hiller et al. (2006: 549, tab. 1) listed a few key morphological characters to distinguish these species. Hiller et al. (2006) identified three distinct color morphs in P. galathinus, namely "White teeth", "Spots", and "Stripes". The "White teeth 2" color morph was recognized during this study in specimens from st. GM10 (see Additional observation and Fig. 3G).

HabitaT. - Most of the specimens of this species were collected at st. GM06, Îlet Fortune, at low tide, on coral rubble and tide pools. Petrolisthes galathinus was also abundant on the coral reef platform at low tide around the Îlet Cabrit. Some specimens were also collected by brushing coral heads in depths of 4-6 m.

Distribution. - Western Atlantic and eastern Pacific. In western Atlantic: from Cap Hatteras, USA, Greater Antilles; Virgin Islands and Lesser Antilles (ICA, Guadeloupe, Barbados; IOV, Margarita, Cubagua, La Tortuga, Los Roques, Bonaire, Curaçao, Aruba), Venezuela, to Santa Catarina, Brazil.

\section{Petrolisthes gertrudae Werding, 1996}

Petrolisthes gertrudae Werding, 1996: 300, figs 1, 2 (type locality: Guadeloupe, also Bonaire). - Werding et al. 2003: 81, tab. 1 (Lesser Antilles).

\section{Material EXAMined. — None.}

DiagnOSIs. — (Adapted from Werding 1996). Carapace smooth; supra-ocular and external orbital angles unarmed; epibranchial region unarmed. Carpus of cheliped anteriorly rounded, sometimes slightly denticulated on proximal portion; dorsal surface granulated; posterior margin unarmed. Palm of cheliped granulated on dorsal surface; anterior and posterior margins unarmed; anterior margin with thick tuft of long setae, not extended onto fixed finger; gape of fingers without pubescence. Ambulatory legs unarmed and devoid of setae on anterior margins; dactylus with four movable spines on posterior margin. Telson composed of seven plates

Remarks. - Although P. gertrudae was originally described from Guadeloupe Island, it was not retrieved during KARUBENTHOS. It cannot be confused with any of the other porcellanid species recognized during the expedition based on the armatures on the carapace, cheliped and ambulatory legs, and the noticeable thick tufts of long setae covering the anterior margin of the palm of the cheliped (see Werding 1996: 307, fig. 1).

HABITAT. - Living on the exposed reef of the upper littoral region, in colony of zoanthid coral Zoanthus fasciatus (Werding, 1996).

Distribution. - Lesser Antilles (ICA, Guadeloupe; IOV, Bonaire).

\section{Petrolisthes hispaniolensis \\ Werding \& Hiller, 2005}

(Fig. 4A)

Petrolisthes hispaniolensis Werding \& Hiller, 2005: figs 1, 2 a-i (type locality: Dominican Republic).

MATERIAL EXAMINED. - Guadeloupe. KARUBENTHOS, 2012,2 o o $3.3 \times 3.2 \mathrm{~mm}, 3.0 \times 2.9 \mathrm{~m}$; 1 \% $3.4 \times$ 3.5 mm. MNHN-IU-2013-7156, st. GM22, lot JL1012.

Diagnosis. - Carapace with few transverse striae on gastric and branchial regions; protogastric ridge elevated; supra-ocular and external orbital angles unarmed; epibranchial region swollen, unarmed. Carpus of cheliped with three or four, inconspicuous, irregular teeth in proximal half of anterior margin, anterodistal angle rounded; posterior margin evenly curved; dorsal surface with oblique rows of granules forming longitudinal crests. Dorsal surface of palm finely granular, with longitudinal shallow groove along anterior margin, extending onto fixed finger; anterior margin unarmed, minutely serrated; posterior margin unarmed; gape of fingers with pubescence. Ambulatory legs unarmed on anterior margins; dactylus with four movable spines on posterior margin. Telson composed of seven plates.

REMARKs. - This is the first record of $P$. hispaniolensis from the Lesser Antilles.

Overall, the morphological characters of the present three specimens agree well with those of $P$. hispaniolensis as described by Werding \& Hiller (2005). Live color is also similar, especially in having "a broad, longitudinal, whitish stripe from the front region to the posterior margin of carapace" (cf. Werding \& Hiller 2005: 1187 , 


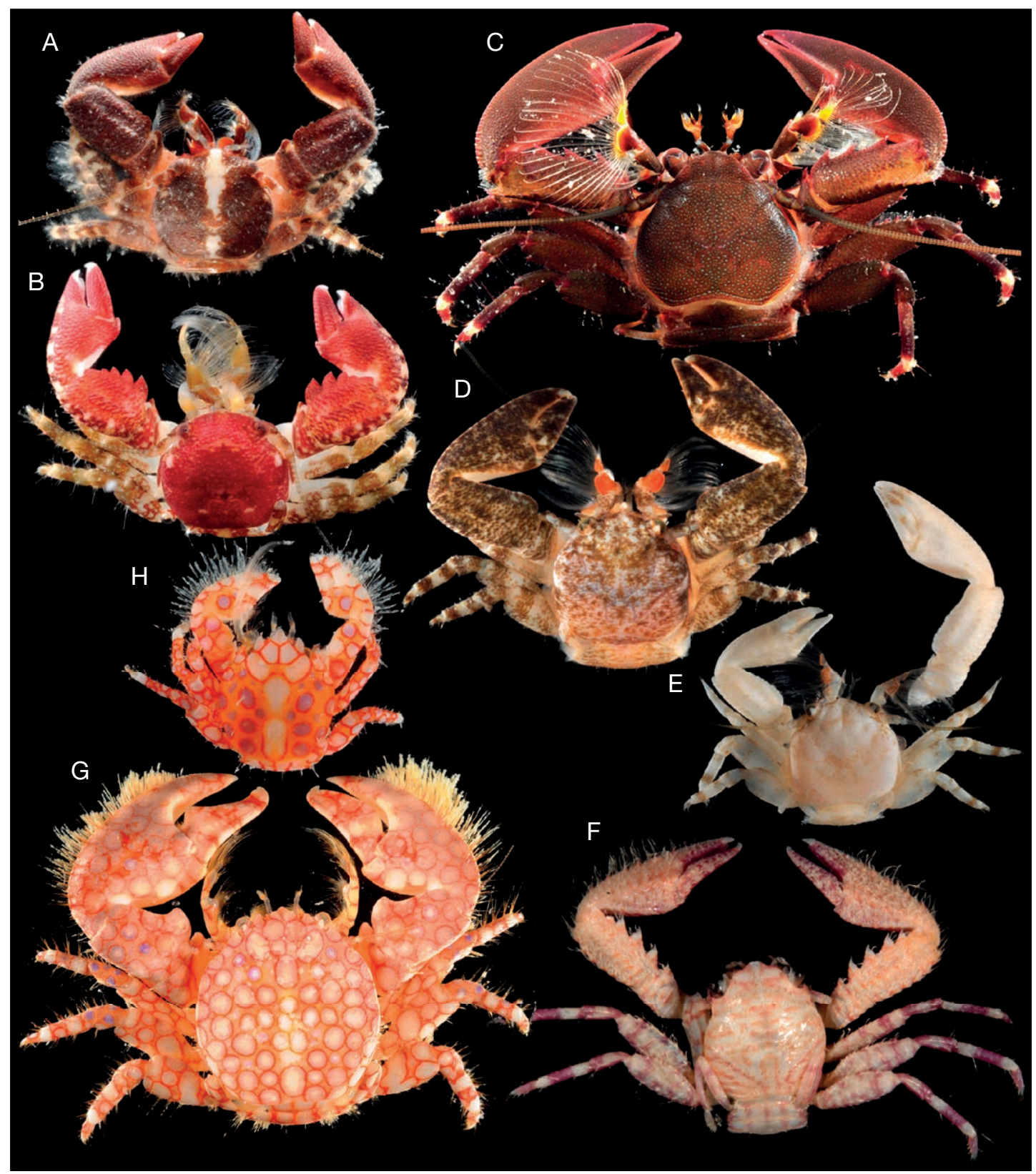

FIG. 4. - A, Petrolisthes hispaniolensis Werding \& Miller, 2005, 1 o $3.3 \times 3.2$ mm, MNHN-IU-2013-7156, st. GM22; B, Petrolisthes jugosus Streets, 1872,1 \% $3.8 \times 4.1 \mathrm{~mm}$, MNHN-IU-2013-5292, st. GM07; C, Petrolisthes politus Gray, 1831,1 ov. $6.0 \times 6.3 \mathrm{~mm}$, MNHN-IU-2013-5076, st. GM07; D, E, Petrolisthes quadratus Benedict, 1901; D, 1 \% $4.0 \times 4.1$ mm, MNHN-IU-2013-5298, st. GM10; E, 1 o $3.5 \times 3.5 \mathrm{~mm}$, MNHN-IU-2013-6886 (right cheliped is detached), st. GM10; F, Petrolisthes rosariensis Werding, 1978, 1 \% $3.3 \times 3.0 \mathrm{~mm}$, MNHN-IU-2013-5427, st. GD20 (preserved specimen); G, Porcellana sayana (Leach, 1820), 1 ơ $9.9 \times 9.1 \mathrm{~mm}$, MNHNIU-2013-4985, st. GR31; H, Porcellana sigsbeiana A. Milne-Edwards, 1880, 1 o $3.1 \times 2.6$ mm, MNHN-IU-2013-5218, st. GB17. Magnification is about $\times 3$ for $\mathrm{C}, \mathrm{G}$, and $\times 5$ for the others species. 
http://www.uni-giessen.de/porcellanidae/). Petrolisthes hispaniolensis belongs to the "P. lewisi" group represented in the western Atlantic by two others species, P. jugosus Streets, 1872 and P. magdalenensis Werding, 1978 (Werding \& Hiller, 2005). It is closer to P. magdalenensis but can be separated by the morphology of the carpus of the chelipeds and live coloration, as documented by Werding \& Hiller (2005: 1189).

HabitaT. - A small species, collected in the intertidal region at low tide, on coral rubble.

Distribution. - Western Atlantic: Dominican Republic and Lesser Antilles (ICA, Guadeloupe).

\section{Petrolisthes jugosus Streets, 1872} (Fig. 4B)

Petrolisthes jugosus Streets, 1872: 134 (type locality: Lesser Antilles, St Martin). — Benedict 1901: 134 (Virgin Islands). — Schmitt 1924a: 74 (Curaçao); 1924b: 88 (Barbados); 1936: 374 (Bonaire). — Haig 1962: 180 (Virgin Islands, Tobago). - Scelzo \& Varela 1988: 41 (La Blanquilla). - Lira 1997: 81, fig. 23 (Margarita). - Werding et al. 2003: 81, tab. 1 (Lesser Antilles). - Rodríguez et al. 2005: 563 (Margarita). — Lira et al. 2012: 23, fig. 2G (La Tortuga).

Pisosoma jugosum - Haig 1956: 16 (Tobago, Cubagua, La Tortuga, Curaçao).

MATERIAL EXAMINED. - Guadeloupe. KARUBENTHOS, 2012, 1 juv. $1.7 \times 1.7 \mathrm{~mm}$, MNHN-IU-2013-5428, st. GM07, lot JL389; 1 \% $3.8 \times 4.1 \mathrm{~mm}, \mathrm{MNHN}-$ IU-2013-5292, st. GM08, lot JL401; 1 o $3.0 \times 2.8$ mm, MNHN-IU-2013-5291, st. GM17, lot JL792b.

REMARKS. - The diagnostic characters of this species are almost the same as those for $P$. hispaniolensis, except for the following characters present in P. jugosus: carpus of cheliped with four large serrated teeth on anterior margin (distalmost tooth smallest), anterodistal angle squared; gape of fingers of cheliped glabrous; telson composed of five plates.

This is the first record of P. jugosus from Guadeloupe Island. Petrolisthes jugosus belongs to the "P. lewisi group" characterized by the possession of longitudinal crests on the dorsal surface of the carpus of the chelipeds. In complement of the morphological characters mentioned herein, P. jugosus can be separated from $P$. hispaniolensis, a species also of the "P. lewisi group", and collected at Guadeloupe, by the carmine red coloration of the chelipeds and carapace, and no whitish stripe on the front to posterior margin of the carapace (compare Figs 4A, B).
HaвiтAT. - Collected in the lower intertidal region at low tide under rocks and coral rubble.

DistRibution. - Western Atlantic: from Florida Keys, USA, Greater Antilles, Virgin Islands and Lesser Antilles (ICA, St Martin, Guadeloupe, Barbados, Tobago; IOV, Cubagua, Margarita, La Blanquilla, La Tortuga, Bonaire, Curaçao), Mexico, Panama, Colombia, to Venezuela.

\section{Petrolisthes politus (Gray, 1831)}

(Fig. 4C)

Porcellana polita Gray, 1831: 14 (type locality: not indicated).

Petrolisthes politus - Stimpson 1859: 74 (Virgin Islands, Barbados). - Schmitt 1936: 374 (Bonaire). — Monod 1939: 559 (Guadeloupe). - Haig 1956: 21 (Curaçao, Tobago); 1962: 178 (Virgin Islands). — Rodríguez 1980: 217, pl. 4 (Los Roques). - Scelzo \& Varela 1988: 41 (La Blanquilla). - Lira 1997: 84, fig. 24 (Margarita, also Aves in distribution). - Werding et al. 2003: 81, tab. 1 (Lesser Antilles). - Rodríguez et al. 2005: 564 (Cubagua, also Aves, Aruba in distribution). - Lira et al. 2012: 24, fig. 2H (La Tortuga).

Petrolisthes magnifica - Schmitt 1924a: 73 (Antigua, Curaçao); 1924b: 89 (Barbados).

MATERIAL EXAMINED. - Guadeloupe. KARUBENTHOS, 2012, 1 ㅇ ov. $6.0 \times 6.3 \mathrm{~mm}$, MNHN-IU-2013-5076, 1 ơ $^{7} 4.9 \times 5.2 \mathrm{~mm}, \mathrm{MNHN}-\mathrm{IU}-2013-6858$, st. GM07, lot JL356; 1 ơ $8.4 \times 9.1 \mathrm{~mm}$, MNHN-IU-2013-5059, st. GM07, lot JL379; 1 ơ $8.0 \times 8.6 \mathrm{~mm}, \mathrm{MNHN}-$ IU-2013-5077, 2 juv., MNHN-IU-2013-5198, st. GM08, lot JL398; 3 juv., MNHN-IU-2013-5217, st. GM33, lot JL1368; 1 juv. $2.9 \times 3.1 \mathrm{~mm}$, MNHN-IU-2013-5591, st. GM33, lot JL1374.

Diagnosis. - Carapace with posterolateral regions expanded, finely granulated to almost smooth; supraocular and external orbital angles unarmed, epibranchial notch unarmed. Carpus of cheliped with three low but distant teeth on anterior margin, and five-six inwardly curved spines on distal half of posterior margin; dorsal surface granulated with some short transverse striae. Chela granulated on dorsal surface, unarmed on anterior and posterior margins; gape of fingers usually glabrous. Ambulatory legs with fringes of setae on anterior margin; merus with three-seven spines on anterior margin; carpus with one anterodistal spine (leg 1) or unarmed (legs 2-3); dactylus with three movable spines on posterior margin. Telson composed of seven plates. 
REMARKS. - The dark brown live coloration illustrated in Fig. 4C is sometimes replaced by a lighter brown tone but the red-brown band across the dactyli of the ambulatory legs appears constant. In juveniles (e.g., juv. $2.9 \times 3.1 \mathrm{~mm}, \mathrm{MNHN}-\mathrm{IU}-2013-5591$, at st. GM33), the small white spots on the carapace and ambulatory legs are replaced by larger, white to light blue spots. Segments of the third maxilliped are generally dark brown, fading to orange on the distal margin of the propodus and most of the surface of the dactylus.

In one male $(8.0 \times 8.6 \mathrm{~mm}, \mathrm{MNHN}-\mathrm{IU}-2013-5077)$, the gape of fingers of only the left cheliped is pubescent on the ventral face. Other specimens examined lack such a tuft of setae.

HabiTAT. - Collected in the intertidal region at low tide among rocks and coral rubble, and limited sandy areas between rocks.

Distribution. - Western Atlantic: from Florida Keys, USA, Bahamas, Greater Antilles, Virgin Islands and Lesser Antilles (ICA, Antigua, Guadeloupe, Barbados, Tobago; IOV, Margarita, Cubagua, La Blanquilla, La Tortuga, Los Roques, Aves, Bonaire, Curaçao, Aruba), Mexico, Belize, Panama, Colombia, to Venezuela.

Petrolisthes quadratus Benedict, 1901 (Fig. 4D, E)

Petrolisthes quadratus Benedict, 1901: 134, pl. 3, fig. 4 (type locality: Ponce, Puerto Rico). - Schmitt 1924a: 73 (Curaçao); 1924b: 89 (Barbados). - Haig 1956: 18 (Cubagua, Curaçao, Aruba); 1962: 176 (Virgin Islands). - Chace \& Hobbs 1969: 121, figs 32, 34a (Dominica). - Scelzo \& Varela 1988: 41 (La Blanquilla). - Werding et al. 2003: 81, tabl. 1 (Lesser Antilles). — Rodríguez et al. 2005: 564 (La Tortuga; also Trinidad, Bonaire in distribution). — Lira et al. 2012: 23, fig. 2E (La Tortuga).

MATERIAL EXAMINED. - Guadeloupe. KARUBENTHOS, 2012, 1 ơ $4.5 \times 4.6 \mathrm{~mm}$, MNHN-IU-2013-5355, st. GM06, lot JL245; 1 ơ $3.5 \times 3.5 \mathrm{~mm}, 2$ 우 $3.4 \times$ 3.4, $4.0 \times 4.1 \mathrm{~mm}, \mathrm{MNHN}-\mathrm{IU}-2013-5298$, st. GM10,

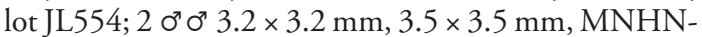
IU-2013-6886, st. GM10, lot JL555.

Diagnosis. - Carapace quadrate, granulated; supraocular and external orbital angles unarmed; epibranchial region unarmed. Carpus of cheliped straight, minutely serrated on anterior margin; posterior margin evenly curved, with transverse low squamae forming a longitudinal crest, distal angle produced and obtusely triangular; dorsal surface granulated, with two shallow longitudinal grooves. Chela glabrous, with dorsal surface granulated, unarmed on anterior and posterior margins; gape of fingers with pubescence. Ambulatory legs unarmed and glabrous on anterior margins; dactylus with four movable spines on posterior margin. Telson composed of seven plates.

REMARKS. - This is the first record of P. quadratus from Guadeloupe Island.

The live coloration shows variations, as illustrated on Fig. 4D, E: the carapace and chelipeds are brown with white speckles (Fig. 4D) or totally cream-white (Fig. 4E). Color pattern of the ambulatory legs is more constant, banded in white and light brown with high (Fig. 4D) or low (Fig. 4E) tones.

Habitat. - Collected in the intertidal region on coral substrate, in tide pools or among rocks and coral rubble. At Dominique Island, Chace \& Hobbs (1969) indicated that this species was very abundant at high tide on the splash zone, at sand level, just below an area of rocks piled upon one another.

Distribution. - Western Atlantic: from Florida Keys, USA, Bahamas, Greater Antilles, Virgin Islands and Lesser Antilles (ICA, Guadeloupe, Dominica, Barbados, Trinidad; IOV, La Blanquilla, Cubagua, La Tortuga, Bonaire, Curaçao, Aruba), Mexico, Belize, Panama, Colombia, to Venezuela.

\section{Petrolisthes rosariensis Werding, 1978}

(Fig. 4F)

Petrolisthes rosariensis Werding, 1978: 214 (type localities: Santa Marta and Nenguange, Colombia). - Werding et al. 2003: 81, tab. 1 (Lesser Antilles; probably from USNM holdings 270473 and 270474, Tobago Island, pers. com. R. Lemaitre).

Material EXAMINED. - Guadeloupe. KARUBENTHOS, 2012,1 o $3.7 \times 3.6 \mathrm{~mm}, 1$ \% $3.3 \times 3.0 \mathrm{~mm}, \mathrm{MNHN}-$ IU-2013-5427, st. GD20, lot JL707b.

Remarks. - This species belongs to the P. galathinus complex with most of the morphological characters similar to those of $P$. caribensis. The main differences with $P$. caribensis are: 1 ) carapace with two epibranchial spines; 2) gape of fingers glabrous; and 3) carpus of ambulatory leg three without anterodistal spine. Within the six species of this complex in the southern Caribbean Sea, $P$. rosariensis is distinctive by the lack of pubescence in the gape of fingers of the cheliped (see Hiller $e t a l$. 2006: 549, tab. 1).

This is the first record of Petrolisthes rosariensis from Guadeloupe Island.

The Guadeloupe specimens have a strong supra-ocular 
spine, with a second spine, unilaterally, on only one specimen, instead of "No strong supra-ocular spine but one to three supra-ocular spinules often present" indicated by Werding (1982) when describing the species. Rodríguez et al. (2005) discussed on the presence or absence of a strong supra-ocular spine in $P$. rosariensis. The present observation in our specimens supports previous suggestion that the development of the supra-ocular spine(s) may be variable in P. rosariensis.

Coloration on a recently preserved specimen (Fig. 4F) shows the ventral surfaces of the chelipeds and ambulatory legs are still purplish, as indicated by Werding (1982), and the ambulatory legs with the same transverse bands on the dactyls, propods and carpi (Fig. 4F) as those illustrated in P. rosariensis by Hiller et al. (2006: 549, http://www.unigiessen.de/porcellanidae/).

Although P. rosariensis was described in detail by Werding (1982), the original description is by Werding (1978), as discussed by Rodríguez et al. (2005: 565). According to data given by Werding (1983: 408, tab. 1) and Hiller et al. (2006: 561, fig. 6), P. rosariensis nests apart from the P. galathinus complex clade, and is more closely related to its eastern Pacific geminate, P. glasselli Haig, 1957 (see Hiller et al. 2006: 558).

HabitaT. - Collected by dredge on flat and soft bottoms, at $35 \mathrm{~m}$.

Distribution. - Western Atlantic: from Greater Antilles, Lesser Antilles (ICA, Guadeloupe, Tobago), Belize, Panama, Colombia to Paraiba, Bahia, Brazil.

\section{Porcellana sayana (Leach, 1820)}

(Fig. 4G)

Pisidia sayana Leach, 1820: 54 (type localities: Georgia and Florida).

Porcellana ocellata - Stimpson 1859: 77 (Virgin Islands).

Porcellana sayana - Schmitt 1924b: 89 (Antigua, Barbados). - Chace 1956: 152 (Los Roques). - Haig 1956: 32 (Coche, Cubagua); 1962: 186 (Virgin Islands). - Gore 1974: 715 (Martinique). — Scelzo \& Varela 1988: 42 (La Blanquilla). — Lira 1997: 117, fig. 34 (Margarita). - Hernández et al. 1999: 27, tab. 1 (Margarita). - Werding et al. 2003: 81, tab. 1 (Lesser Antilles). - Rodríguez et al. 2005: 564 (Margarita). — Lira et al. 2012: 27, fig. 3F (La Tortuga).

MATERIAL EXAMINED. - Guadeloupe. KARUBENTHOS, 2012, 1 sp. MNHN-IU-2013-4986, 1 sp. MNHNIU-2013-5063, 1 sp. MNHN-IU-2013-5064, st. GD33, lot JL925; 1 o" $9.9 \times 9.1 \mathrm{~mm}$, MNHN-IU-2013-4985, $1 \mathrm{sp}$. MNHN-IU-2013-5061, st. GR31, lot JL955; 1 ơ $6.0 \times$ 5.5 mm, MNHN-IU-2013-5425, st. GR27, lot JL836.
Diagnosis. - Carapace minutely granulate, with fine oblique plications on branchial regions; front tridentate with margins slightly tuberculate; supra-ocular angle produced into a frontal lateral tooth reaching about midlength of rostrum; external orbital angle produced into broad tooth; epibranchial region with shallow indentation, sometimes with terminal spine. Anterior margin of carpus of cheliped unarmed, proximal half produced into broad lobe, anterodistal angle rounded; posterior margin slightly curved, unarmed. Carpus and chela with low plications, almost smooth on dorsal surfaces. Chela fringed with long plumose setae on anterior margin; posterior margin rounded, unarmed; gape of fingers glabrous. Ambulatory legs unarmed on anterior margins, with sparse long setae; dactylus with four movable spines on posterior margin. Telson composed of seven plates.

REMARKS. - This is the first record of P. sayana from Guadeloupe Island.

Porcellana sayana is a common species that can be recognized in situ based on its color pattern and the presence of a broad proximal lobe on the anterior margin of the carpus of the cheliped.

HABITAT. - Common in shallow-waters in a variety of habitats. During KARUBENTHOS it was collected during scuba dives at depths of $8-14 \mathrm{~m}$ and by dredging at $130 \mathrm{~m}$ the deepest record for this species (previously known to $110 \mathrm{~m}$ ). López-Victoria et al. (2004) reported symbiotic relationships between $P$. sayana, the hermit crab Dardanus fucosus Biffar \& Provenzano, 1972 and the sea anemone Calliactis tricolor (Lesueur, 1817). Recently, more associations were also reported by Lira et al. (2012: 28), with other hermit crabs, Dardanus venosus (H. Milne Edwards, 1848), Paguristes grayi Benedict, 1901, Paguristes puncticeps Benedict, 1901, Pagurus pollicaris Say, 1817, Paguristes tortugae Schmitt, 1933, Petrochirus diogenes (Linnaeus, 1758), the brachyuran crab, Stenocionops furcatus (Olivier, 1791), the gastropod, Lobatus gigas (Linnaeus, 1758), and the holothurian, Astichopus multifidus (Sluiter, 1910).

DistRIBUTION. - Western Atlantic: from North Carolina, USA, Bahamas, Greater Antilles, Virgin Islands and Lesser Antilles (ICA, Antigua, Guadeloupe, Martinique, Barbados; IOV, Coche, Margarita, Cubagua, La Blanquilla, La Tortuga, Los Roques), Mexico, Belize, Panama, Colombia, Venezuela, Guyanas, to Rio Grande do Sul, Brazil.

\section{Porcellana sigsbeiana A. Milne-Edwards, 1880} (Fig. 4H)

Porcellana sigsbeiana A. Milne-Edwards, 1880: 35 (Virgin Islands). — Gore 1974: 716 (Trinidad, Margarita). - Werding et al. 2003: 81, tab. 1 (Lesser Antilles). 
TABLE 2. - List of porcellanid crabs in the Lesser Antilles and Virgin Islands. This list is an update based on Werding et al. (2003), Rodríguez et al. (2005), additional localities found in references (e.g., Lira et al. 2007; 2012), and new records documented herein. A distinction is made of Virgin Islands, ICA and IOV (see Fig. 1B). Abbreviations: ICA, Islands of the Caribbean arc; IOV, Islands off the Venezuelan coast; VI, Virgin Islands; *, new records.

\section{$\frac{\text { Species }}{\text { 1. Clastotoechus nodosus (Streets, 1872) }}$ \\ 2. Clastotoechus vanderhorsti (Schmitt, 1924) \\ 3. Megalobrachium mortenseni Haig, 1962 \\ 4. Megalobrachium poeyi (Guérin, 1855)}

5. Megalobrachium roseum (Rathbun, 1900)

6. Megalobrachium soriatum (Say, 1818)

7. Neopisosoma angustifrons (Benedict, 1901)

8. Neopisosoma curacaoense (Schmitt, 1924)

9. Neopisosoma neglectum Werding, 1986

10. Neopisosoma orientale Werding, 1986

11. Pachycheles ackleianus A. Milne-Edwards, 1880

12. Pachycheles chacei Haig, 1956

13. Pachycheles monilifer (Dana, 1852)

14. Pachycheles pilosus (H. Milne Edwards, 1837)

15. Pachycheles riisei (Stimpson, 1859)

16. Pachycheles rugimanus A. Milne-Edwards, 1880

17. Pachycheles serratus (Benedict, 1901)

18. Pachycheles susanae Gore \& Abele, 1973

19. Parapetrolisthes tortugensis (Glassell, 1945)

20. Petrolisthes amoenus (Guérin, 1855)

21. Petrolisthes armatus (Gibbes, 1850)

22. Petrolisthes caribensis Werding, 1983

23. Petrolisthes dissimulatus Gore, 1983

24. Petrolisthes galathinus (Bosc, 1802)

25. Petrolisthes gertrudae Werding, 1996

26. Petrolisthes hispaniolensis Werding \& Hiller, 2005

\section{VI}

St Martin

$x$ Saba, Martinique, Barbados

$x$ Guadeloupe*

$x$ Antigua and Barbuda, Guadeloupe*, Martinique, Barbados, Tobago

Martinique

Guadeloupe*, Martinique, Margarita Barbados

x Saba, St Eustatius, Guadeloupe, Trinidad

$x \quad$ Saba, St Martin, St Eustatius, Guadeloupe*, Grenada

St Martin, Grenada

Trinidad

$x$ Antigua, Martinique, St Lucia, Barbados

$x \quad$ Trinidad

x Guadeloupe, Barbados, Tobago

$x$ Barbados, Tobago

$x$

$\mathrm{x}$

Martinique

x Guadeloupe*

x Antigua, Guadeloupe*, St Lucia, Barbados, Grenada, Tobago

x Guadeloupe*, Trinidad

\section{Margarita, Cubagua,} La Tortuga, Bonaire, Curaçao, Aruba

Cubagua, La Tortuga, Bonaire, Curaçao, Aruba

Margarita

Los Testigos, Margarita, Los Roques

Margarita

Margarita, Cubagua, La Tortuga

La Blanquilla, La Tortuga, Aves, Bonaire, Curaçao, Aruba

Margarita, Cubagua, La Tortuga

Margarita

Coche, Cubagua, La Tortuga

La Tortuga

Cubagua, La Tortuga, Los Roques, Bonaire, Curaçao

Margarita, Cubagua, La Blanquilla, La Tortuga, Curaçao

St Martin*, Guadeloupe*, Bonaire*, Curaçao* Martinique*

x Guadeloupe*, Martinique, Curaçao Barbados

$x \quad$ Guadeloupe, Barbados

Margarita, Cubagua, La Tortuga, Los Roques, Bonaire, Curaçao, Aruba

Guadeloupe Guadeloupe* 


\begin{abstract}
$\frac{\text { Species }}{\text { 27. Petrolisthes jugosus (Streets, 1872) }}$
29. Petrolisthes marginatus Stimpson, 1859
\end{abstract}

30. Petrolisthes politus (Gray, 1831)

31. Petrolisthes quadratus Benedict, 1901

32. Petrolisthes rosariensis Werding, 1978

33. Petrolisthes tonsorius Haig, 1960

34. Petrolisthes tridentatus Stimpson, 1859

35. Pisidia brasiliensis Haig in Rodrigues da Costa, 1968

36. Porcellana sayana (Leach, 1820)

37. Porcellana sigsbeiana A. Milne-Edwards, 1880
VI

x St Martin, Guadeloupe*, Barbados, Tobago

$\begin{array}{cc} & \text { Tobago, Trinidad } \\ \text { x } & \text { Dominica, Trinidad, } \\ & \text { Tobago } \\ \text { x } \quad \text { Antigua, Guadeloupe, } \\ \text { Barbados, Tobago }\end{array}$

$\mathrm{X}$

Guadeloupe*, Dominica, Barbados, Trinidad

Guadeloupe*, also "Lesser Antilles" without precision in Werding et al. (2003)

x Antigua, Barbados, Trinidad

x Antigua, Guadeloupe*, Martinique, Barbados

\section{IOV}

Cubagua, Margarita, La Blanquilla, La Tortuga, Bonaire, Curaçao

Margarita Margarita, Los Roques, Aves, Bonaire, Curaçao Margarita, Cubagua, La Blanquilla, La Tortuga, Los Roques, Aves, Bonaire, Curaçao, Aruba

La Blanquilla, Cubagua, La Tortuga, Bonaire, Curaçao, Aruba

Margarita

Margarita, Cubagua

\section{Margarita}

Coche, Margarita, Cubagua, La Blanquilla, La Tortuga, Los Roques Margarita
MATERIAL EXAMINED. - Guadeloupe. KARUBENTHOS, 2012, 1 o' $3.1 \times 2.6 \mathrm{~mm}$, MNHN-IU-2013-5218, st. GB17, lot JL876.

DiAGNOSIS. - Carapace smooth; front strongly tridentate, with margins entire; supra-ocular angle produced as frontal lateral tooth reaching about midlength of rostrum, external orbital angle produced into strong tooth; epibranchial region with deep $\mathrm{V}$-shaped indention and minute terminal spine. Anterior margin of carpus of cheliped almost straight, with minute denticle on proximal half; posterior margin slightly curved, terminating into distal spine; dorsal face smooth. Dorsal surface of chela smooth, anterior margin minutely serrated, with fringe of long plumose setae; posterior margin rounded, unarmed; gape of fingers glabrous. Ambulatory legs unarmed but with sparse long setae on anterior margins; dactylus with four movable spines on posterior margin. Telson composed of seven plates.

REMARKS. - This is the first record of P. sigsbeiana, from Guadeloupe Island.

The present small specimen keyed out to P. sigsbeiana by using Lemaitre \& Campos (2000) key. It is close to Porcellana lillyae Lemaitre \& Campos, 2000, but differs in: 1) the margins of rostrum and lateral teeth of front (supra-ocular angle) are entire, instead of dentate; 2) the ventral margin of rostrum are unarmed, instead of bearing two-four small spines; and 3) the anterior margin of carpus of cheliped has a single proximal spine, instead of entirely spinulose.

HABITAT. - On rocky bottoms in shallow-waters, at a depth of $13 \mathrm{~m}$. Collected by brushing on coral heads.

DistribuTION. - Western Atlantic: from Massachusetts, USA, Greater Antilles, Virgin Islands and Lesser Antilles (ICA, Guadeloupe, Trinidad; IOV, Margarita), Mexico, Honduras, Colombia, Venezuela, Suriname, to Pará and Maranhao, Brazil.

\section{DISCUSSION}

Fifteen species collected during this study represent new records for Guadeloupe Island, bringing to 20 the total number of porcellanids species known from this island. A new record for the Lesser Antilles fauna is $P$. hispaniolensis, and two new records for the 
islands of the Caribbean arc (ICA) are M. mortenseni and $P$. tortugensis.

Although the 2012 KARUBENTHOS Expedition was an intensive effort that sampled about 270 stations, it is probable that the porcellanid inventory is still incomplete due to bias in collecting methods or lack of samplings in some habitats. An indication of inventory incompleteness is supplied by the absence in our samples of $P$. gertrudae, a species originally described from Guadeloupe Island and nevertheless not collected during KARUBENTHOS.

As Guadeloupe Island occupies a sub-central place in the Caribbean arc (Fig. 1B), its potential for porcellanid crab biodiversity is high, and probably contains most of the 37 species now known from the entire Virgin Islands and Lesser Antilles, as presented in Table 2.

\section{Acknowledgements}

The specimens studied herein were collected in Guadeloupe, in May 2012, during the KARUBENTHOS Expedition. This Expedition (principal investigator Philippe Bouchet) was organized jointly by the National Park of Guadeloupe, the MNHN, the UAG, and the UPMC. During the expedition, Laure Corbari helped to handle and photograph crustaceans. In MNHN and during the Besse March 2013 sorting workshop, the helps of Rachid Kebir, Paula Martin-Lefevre, and Anouchka Sato were greatly appreciated. Participation in KARUBENTHOS Expedition (first author) and the Besse sorting workshop (first and second authors) was sponsored via a Europe funding (FEDER), the Port Autonome de la Guadeloupe (PAG) and the French administration. The French Navy School has greatly facilitated the participation of the first author in this research program. Darryl Felder, Alexandra Hiller, Irene Teresa Rodríguez, and Bernd Werding made useful comments and suggestions during the preparation of the manuscript. Alexandra Hiller and an anonymous reviewer helped to improve this work.

\section{REFERENCES}

Benedict J. E. 1901. - The Anomuran collection made by the Fish Hawk Expedition to Porto Rico.
Bulletin of the U.S. Fish Commission for 1900, 20 (2): 129-148, pls 3-6.

BosC L. A. G. 1802. - Histoire naturelle des Crustacés, contenant leur description et leurs moeurs, avec figures dessinées d'après nature. Vol. 2. Paris, Deterville: 296 p., pls 9-18.

CHACE F. A. 1956. - Crustáceos decápodos y estomatópodos del Archipiélago de los Roques e Isla de la Orchilla, in MÉndEZ A. et al. (eds), El Archipiélago Los Roques y La Orchilla. Sociedad de Ciencias Naturales La Salle, Caracas: 145-168, 9 unnumbered photographs.

Chace F. A. \& Hobbs H. H. 1969. - The freshwater and terrestrial decapod crustaceans of the West Indies with special reference to Dominica. Bredin-ArchboldSmithsonian Biological Survey of Dominica. United States National Museum Bulletin 292: i-v, 1-258, figs 1-76, pls 1-5.

Doflein F. 1899. - Amerikanische Dekapoden der k. bayerischen Staatssammlungen. Sitzungsberichte der Mathematischen-Physikalischen Klasse der Königlich Bayerischen Akademie der Wissenschaften zu München 29: 177-195.

Felder D. L., Álvarez F., Goy J. W. \& Lemaitre R. 2009. - Decapoda (Crustacea) of the Gulf of Mexico, with comments on the Amphionidacea, in FELDER D. L. \& CAMP D. K. (eds) Gulf of Mexico Origin, Waters, and Biota. Volume 1, Biodiversity. College Station, Texas A\&M University Press, Texas: 10191104, 11 figs.

GibBes L. R. 1850. - On the carcinological collections of the United States, and an enumeration of species contained in them, with notes on the most remarkable, and descriptions of new species. Proceedings of the American Association for the Advancement of Science 3: 167-201.

Glassell S. A. 1945. - Four new species of North American crabs of the genus Petrolisthes. Journal of the Washington Academy of Sciences 35: 223-229.

GUÉRIN-MÉNEVILLE F. E. 1855. — Crustáceos, arágnides e insectos, in DE la SAGRa R. (ed.) Historia física, política y natural de la isla de Cuba. Vol. 8. Atlas de Zoología, Paris: pl. 1-20.

Gore R. H. 1974. - Biological results of the University of Miami deep-sea Expedition. 102. On a small collection of porcellanid crabs from the Caribbean sea (Crustacea, Decapoda, Anomura). Bulletin of Marine Sciences 24 (3): 700-721, figs 1-5.

Gore R. H. 1983. - The identity of Petrolisthes marginatus Stimpson, 1859, and the description of Petrolisthes dissimulatus n. sp. (Crustacea: Decapoda: Porcellanidae). Proceedings of the Biological Society of Washington 96 (1): 89-102, figs 1-4.

Gore R. H. \& Abele L. G. 1974. - Three New Species of Porcellanid Crabs (Crustacea, Decapoda, Porcellanidae) from the Bay of Panama and Adjacent Caribbean Waters. Bulletin of Marine Sciences 23 (3): 559-573, figs 1-3. 
Gore R. H. \& Abele L. G. 1976. - Shallow water porcelain crabs from the Pacific coast of Panama and adjacent Caribbean waters (Crustacea: Anomura: Porcellanidae). Smithsonian Contributions to Zoology 237: 1-30, figs 1-4.

GRAY J. E. 1831. - Description of the species of Porcellana, in the collection of the British Museum. The Zoological Miscellany 1: 14-16.

HAIG J. 1956. — The Galatheidea (Crustacea Anomura) of the Allan Hancock Atlantic Expedition with a review of the Porcellanidae of the western North Atlantic. Allan Hancock Atlantic Expedition Report 8: 1-44, pl. 1.

HAIG J. 1960. — The Porcellanidae (Crustacea, Anomura) of the Eastern Pacific. Allan Hancock Foundation Pacific Expedition 24: v-vii, 1-440, figs 12, pls 1-41.

HaIG J. 1962. — Papers from Dr. Th. Mortensen's Pacific Expedition 1914-1916. 79. Porcellanid crabs from eastern and western America. Videnskabelige meddelelser fra Dansk naturhistorisk forening i Kjøbenhavn 124: 171-192, figs 1-5.

HeRnÁNDEZ G., LaRES L. \& Bolaños J. 1999. —Crustáceos decápodos bentónicos del monumento natural de la Laguna de las Marites, Isla de Margarita. Boletín del Instituto Oceanográfico de Venezuela 38 (2): 25-32, figs 1-2.

Hiller A., Kraus H., Almon M. \& Werding B. 2006. - The Petrolisthes galathinus complex: Species boundaries based on color pattern, morphology and molecules, and evolutionary interrelationships between this complex and other Porcellanidae (Crustacea: Decapoda: Anomura). Molecular Phylogenetics and Evolution 40 (2): 547-569, figs 1-6.

LEACH W. E. 1820. — Galatéadées, Galateadx. (Crust.), in Cuvier F. (ed.) Dictionnaire des Sciences Naturelles, dans lequel on trait Méthodiquement des Différens êtres de la Nature, considérés soit en eux-mêmes, d'après l'état actuel de nos connoissances, soit relativement a l'utilité qu'en peuvent retirer la Médecine, l'Agriculture, le Commerce et les Arts. Vol. 18. Strasbourg et Paris: F. G. Levrault et Le Normant: 49-56 p.

Lemaitre R. \& CAmpos N. H. 2000. - Porcellana lillyae, New Species (Decapoda, Anomura, Porcellanidae), from the Caribbean Sea, with a key to the Western Atlantic Species of the Genus. Journal of Crustacean Biology 20 (2): 259-265, figs 1-4.

LiRA C. 1997. - Crustáceos anomuros costeros de la Península de Macanao, Isla de Margarita, Venezuela. Magister Scientiarum En Ciencias Marinas, Universidad de Oriente, Cumaná: 1-201, figs 1-38.

Lira C., Hernández G. \& Bolaños J. 2001. - Cangrejos porcelánidos (Decapoda: Anomura) de las islas orientales de Venezuela. I-El género Megalobrachium Stimpson, 1858, con dos adiciones a la carcinofauna Venezolana. Boletín del Instituto Oceanográfico de Venezuela 40 (1-2): 55-66, figs 1-4.

lira C., Hernández G. \& Bolaños J. A. 2003. - Un caso de malformación en Pachycheles serratus (Decapoda:
Porcellanidae). Revista de Biología Tropical 51, Suppl. 4: 149-151, fig. 1.

lira C., Hernández G., Bolaños J., Graterol K. \& PIÑATE M. 2007. - Cangrejos porcelánidos (Decapoda: Anomura) de Las Islas Nororientales de Venezuela. II - El Género Pachycheles Stimpson, 1858. Boletín del Instituto Oceanográfico de Venezuela 46 (1): 37-50, figs 1-7.

lira C., Hernández G., Bolaños J., Hernández J., López R., Piñate M. \& Hernández Ávila I. 2012. - Crustáceos decápodos bentónicos litorales de la isla de La Tortuga. I - Familia Porcellanidae Haworth, 1825. Boletín del Instituto Oceanográfico de Venezuela 51 (1): 19-33, figs 1-3.

lópez-Victoria M., Barrios L., M. Kraus H. \& OsORIO L. A. 2004. - New aspects on the symbiotic relationships between Dardanus fucosus (Crustacea: Paguridae), Calliactis tricolor (Cnidaria: Hormathiidae) and Porcellana sayana (Crustacea: Porcellanidae). Boletín Investigaciones Marinas y Costeras 33: 261-264.

Milne EdWardS H. 1837. - Histoire naturelle des crustacés, comprenant l'anatomie, la physiologie et la classification de ces animaux. Vol. 2. Atlas, Paris: $532 \mathrm{p}$.

MiLNE-EDWARDS A. 1880. - Reports on the results of dredging, under the supervision of Alexander Agassiz, in the Gulf of Mexico, and in the Caribbean Sea, 1877, '78, '79, by the United States Coast Survey Steamer "Blake," Lieut.-Commander C.D. Sigsbee, U.S.N., and Commander J.R. Bartlett, U.S.N., commanding. VIII. Études préliminaires sur les crustacés. Bulletin of the Museum of Comparative Zoölogy at Harvard College 8 (1): 1-68, pls 1-2.

Milne-EDwARDS A. \& BOUvier E. L. 1923. — Reports on the results of dredging under the supervision of A. Agassiz, in the gulf of Mexico (1877-78), in the Caribbean Sea (1878-79), and along the Atlantic coast of the United States (1880), by the U.S. coast survey steamer Blake. XLVII Les Porcellanides et les Brachyures. Memoirs of the Museum of Comparative Zoology at Harvard College 47 (4): 283-395, pls 1-12.

MONOD T. 1939. - Sur quelques crustacés de la Guadeloupe (Mission P. Allorge, 1936). Bulletin du Muséum national d'histoire naturelle, Paris, série 2, 11 (6): 557-568, figs 1-11.

NobiLi G. 1898. - Crostacei Decapodi e Stomatopodi di St. Thomas (Antille). Bollettino dei Musei di Zoologia ed Anatomia comparata della R. Università di Torino 13 (314): 1-3.

OSAWA M. \& Chan T.-Y. 2010. — Part III. Porcellanidae (Porcelain crabs), pp. 67-197, in CHAN T.-Y. (ed.) Crustacean Fauna of Taiwan: Crab-Like Anomurans (Hippoidea, Lithodoidea, and Porcellanidae). National Taiwan Ocean University, Keelung: 67-195, figs 46-142.

Rathbun M. J. 1919. — Stalk-Eyed Crustaceans of the Dutch West Indies, in BoeKE, D.J. (ed.) Rapport betreffende een voorloopig onderzoek naar den toestand van de visscherij en de industrie van zeeproducten in de 
kolonie Curaçao, ingevolge het ministerieel besluit van 22 November 1904, 2: 317-349 [reprint, 1-32], figs 1-5.

Rodríguez G. 1980. — Crustáceos Decápodos de Venezuela. Instituto Venezolano de Investigaciones Científicas, Caracas, 1-494, figs 1-119, pls 1-70.

Rodríguez I. T., Hernández G. \& Felder D. L. 2005. - Review of the Western Atlantic Porcellanidae (Crustacea: Decapoda: Anomura) with new records, systematic observations, and comments on biogeography. Caribbean Journal of Science 41 (3): 544-582, pl. 1.

Rodríguez I. T., Hernández G. \& Felder D. L. 2006. - Phylogenetic relationships among western Atlantic Porcellanidae (Decapoda: Anomura), based on partial sequences of the mitochondrial $16 S$ rRNA gene, with comments on morphology, in AsaKura A. (ed.), Biology of Anomura II. Crustacean Research, Special number 6: 151-166, figs 1-2.

SAY T. 1818. - Appendix to the account of the Crustacea of the United States. Journal of the Academy of Natural Sciences of Philadelphia 1: 445-458.

SCELzo M. A. 1984. - Observaciones sobre la fauna de crustáceos porcelánidos en la bahía Charagato, isla Cubagua, Venezuela (Crustacea: Anomura: Porcellanidae). Acta científica venezolana 35 (supl. 1): 374.

Scelzo M. A. \& Varela R. J. 1988. - Crustáceos Decápodos Litorales de la Isla La Blanquilla, Venezuela. Memorias de la Sociedad de Ciencias Naturales 47(129): 33-53, figs 1-3.

SchmiтT W. L. 1924a. - The macruran, anomuran, and stomatopod Crustacea. Bijdragen tot de Kennis der Fauna von Curaçao. Resultaten eener reis van Dr. C. J. van der Horst in 1920. Bijdragen tot de Dierkunde 23: 61-81, figs 1-7, pl. 8.

SchmitT W. L. 1924b. - Report on the Macrura, Anomura, and Stomatopoda collected by the BarbadosAntigua expedition from the University of Iowa in 1918. Studies in Natural History, Iowa University 10 (4): 65-99, pls 1-5.

Sснмітт W. L. 1936. — Zoologische Ergebnisse einer Reise nach Bonaire, Curaçao und Aruba im Jahre 1930. No. 16. Macruran and anomuran Crustacea from Bonaire, Curaçao and Aruba. Zoologische Jahrbücher. Abteilung für Systematik, Ökologie und Geographie der Tiere 67 (5-6): 363-378, pls 11-13.

SchмiтT W. L. 1957. - A Narrative of the SmithsonianBredin Caribbean Expedition, 1956. General Appendix in Annual Report of the Board of Regents of the Smithsonian Institution for 1956: 443-460, pls 1-8.

STIMPSON W. 1858. — Prodromus descriptionis animalium evertebratorum, quae in Expeditione ad Oceanum Pacificum Septentrionalem, a Republica Federata missa, Cadwaladaro Ringgold et Johanne Rodgers ducibus, observavit et descripsit. Pars VII. Crustacea Anomura. Proceedings of the Academy of Natural Sciences of Philadelphia 10 (7): 225-252.

STIMPSON W. 1859. - Notes on North American Crustacea, No. 1. Annals of the Lyceum of Natural History of New York 7: 49-93, pl. 1.

STREETS T. H. 1872. - Notice of some Crustacea from the island of St. Martin, W. I., collected by Dr. Van Rijgersma. Proceedings Academy Natural Sciences Philadelphia 24: 131-134.

WeRDING B. 1978. — Los porcelánidos (Crustacea: Anomura: Porcellanidae) de la región de Acandí (Golfo de Urabá), con algunos encuentros nuevos de la región de Santa Marta (Colombia). Anales del Instituto de Investigaciones Marinas de Punta de Betin 10: 213-221, figs 1, 2.

WERDING B. 1982. — Porcellanid crabs of the Islas del Rosario, Caribbean coast of Colombia, with a description of Petrolisthes rosariensis new species (Crustacea: Anomura). Bulletin of Marine Science 32 (2): 439-447, figs 1-3.

Werding B. 1983. - Der Petrolisthes galathinusArtenkomplex im karibischen Raum mit Beschreibung von $P$. caribensis n. sp. und $P$. columbiensis n. sp. (Crustacea: Anomura: Porcellanidae). Senckenbergiana Biologica 63 (5/6): 407-418, figs 1, 2.

WerdiNG B. 1986. — Die Gattung Neopisosoma Haig, 1960 im tropischen Westatlantik, mit der Beschreibung von Neopisosoma neglectum spec. nov. und Neopisosoma orientale spec. nov. (Crustacea: Anomura: Porcellanidae). Zoologische Mededelingen 60 (11): 159-179, figs 1-6.

WERDING B. 1996. - Description of a new porcellanid, Petrolisthes gertrudae from the southeastern Caribbean Sea (Crustacea: Decapoda: Porcellanidae). Proceedings of the Biological Society of Washington 109: 306-310, figs $1,2$.

Werding B. \& Hiller A. 2005. - A new porcellanid species from the Caribbean Sea, with a discussion on the American "Petrolisthes lewisi-group" (Decapoda, Anomura, Porcellanidae). Crustaceana 78 (10): 11851190, figs 1, 2.

Werding B. Hiller A. \& Lemaitre R. 2003. - Geographic and depth distributional patterns of western Atlantic Porcellanidae (Crustacea: Decapoda: Anomura), with an updated list of species. Memoirs of Museum Victoria 60 (1): 79-85, figs 1, 2.

Williams A. B. 1984. - Shrimps, lobsters, and crabs of the Atlantic coast of the eastern United States, Maine to Florida. Smithsonian Institution Press, Washington D.C. v-xviii, 1-550, figs 1-380. 
